\title{
Monitoring the Redox Status in Multiple Sclerosis
}

\author{
Masaru Tanaka ${ }^{1,2}$ and László Vécsei 1,2,* \\ 1 MTA-SZTE, Neuroscience Research Group, Semmelweis u. 6, Szeged, H-6725 Hungary; \\ tanaka.masaru.1@med.u-szeged.hu \\ 2 Department of Neurology, Interdisciplinary Excellence Centre, Faculty of Medicine, University of Szeged, \\ Semmelweis u. 6, H-6725 Szeged, Hungary \\ * Correspondence: vecsei.laszlo@med.u-szeged.hu; Tel.: +36-62-545-351
}

Received: date; Accepted: date; Published: date

\begin{abstract}
:
Worldwide, over 2.2 million people are suffered from multiple sclerosis (MS), a multifactorial demyelinating disease of the central nervous system, characterized by multifocal inflammatory or demyelinating attacks associated with neuroinflammation and neurodegeneration. The blood, cerebrospinal fluid, and postmortem brain samples of MS patients evidenced the presence of reduction-oxidation (redox) homeostasis disturbance such as the alternations of oxidative and antioxidative enzyme activities and the presence of degradation products. This review article discussed the components of redox homeostasis including reactive chemical species, oxidative enzymes, antioxidative enzymes, and degradation products. The reactive chemical species covered frequently discussed reactive oxygen/nitrogen species, rarely featured reactive chemicals such as sulfur, carbonyls, halogens, selenium, and nucleophilic species that potentially act as reductive as well as pro-oxidative stressors. The antioxidative enzyme systems covered the nuclear factor erythroid-2-related factor 2 (NRF2)-Kelch-like ECH-associated protein 1 (KEAP1) signaling pathway, a possible biomarker sensitive to the initial phase of oxidative stress. Altered components of the redox homeostasis in MS were discussed, some of which turned to be MS subtype- or treatment-specific and thus potentially become diagnostic, prognostic, predictive, and/or therapeutic biomarkers. Finally, monitoring a battery of redox components including oxidative, antioxidative and degradation products helps evaluate the redox status of MS patients, which expedites prolongation of remission, relapse prevention, and building personalized treatment plans.
\end{abstract}

Keywords: oxidative stress; redox; antioxidant; multiple sclerosis; biomarker; neurodegenerative disease; personalized medicine

\section{Introduction}

Multiple sclerosis (MS) is an immune-mediated demyelinating disease of the brain and spinal cord, which suffers over 2.2 million people worldwide and affects primarily young adults of 20 and 40 years of age. After one to two decades many patients with MS enter a progressive phase of the disease. As survival has been improved, MS patients are suffered throughout adult life. Years lived with disability (YLDs) begin to increase steeply early in the second decade of life and disabilityadjusted life years (DALYs) peak in the sixth decade of life [1]. MS encompasses a wide range of symptoms from motor and autonomic dysfunctions to psychobehavioral disturbances including gait difficulties, paresthesia, spasticity, vision problems, dizziness and vertigo, incontinence, constipation, sexual disturbances, pain, cognitive and emotional changes, anxiety, and depression $[2,3,4,5]$.

Several genetic susceptibility and environmental factors have been proposed to alter the risk of developing MS, but the underlying cause of the disease remains unknown [6,7]. The most typical pathomechanism involved in MS is simultaneous inflammatory and neurodegenerative processes 
[8,9]. Main pathological findings of MS include the blood-brain barrier disruption, multifocal inflammation, demyelination, oligodendrocyte loss, reactive gliosis, and axonal degeneration [10]. Multifocal immune-mediated destruction of myelin and oligodendrocytes leading to progressive axonal loss is a main cause of neurological deficits in MS [11,12,13].

The diagnosis of MS is confirmed by the presence of two or more multifocal inflammatory or demyelinating attacks in central nervous system (CNS) with objective clinical evidence, a single attack with magnetic resonance imaging (MRI)-detected lesions and positive cerebrospinal fluid (CNF) analysis, or insidious neurological progression with positive brain MRI or CSF analysis [14]. The symptomatic course classifies MS into four subtypes. Approximately $85 \%$ of MS patients have alternating episodes of neurological disability and recovery which last for many years, termed relapsing-remitting MS (RRMS). Almost 90\% of RRMS patients progress to steady neurological decline within 25 years, termed secondary progressive MS (SPMS). Nearly $10 \%$ of MS patients are suffered from steady deterioration of neurological functions without recovery, termed primary progressive MS (PPMS). As few as 5\% of MS patients present progressive neurological deficits with acute attacks with or without recovery, termed progressive-relapsing MS (PRMS) [15]. However, PRMS is no longer considered a subtype of MS and now grouped into PPMS with active disease of new symptoms or changes on MRI scan [16]. In addition, clinically isolated syndrome (CIS) is a single episode of monofocal or multifocal neurological deficits that lasts at least 24 hours. CIS is one of the MS disease courses [10].

MS, as in other neurodegenerative diseases, is a clinically classified disease of CNS in which multifactorial factors including genetic, environmental, socioeconomic, cultural, and personal lifestyle, play an initial role to form a heterogenous causative complex, eventually converging into similar pathognomonic clinical and pathological pictures [4]. Inflammatory and demyelinating attacks are unique manifestations in MS, but different pathomechanisms govern the distinguished clinical courses in each subtype of MS.

Currently there is no cure for MS. Disease modifying therapy is the mainstay of MS treatment. Immunomodulators, immunosuppressors, and cytotoxic agents are main groups of drugs. Immunomodulators such as interferon beta (IFN- $\beta$ ) and glatiramer acetate (GA) are used for CIS. Short courses of high-dose corticosteroid methylprednisolone alleviate acute flare-ups of RRMS, evidencing that an inflammatory process predominates in RRMS and relapse prevention of RRMS [17]. For active RRMS monoclonal antibodies alemtuzumab and ocrelizumab, and immunomodulator dimethyl fumarate, fingolimod, and teriflunomide are prescribed besides IFN- $\beta$ and GA. For highly active RRMS, cytotoxic agents cladribine and mitoxantrone are indicated, besides immunomodulatory fingolimod, and monoclonal antibodies, natalizumab and ocrelizumab. PPMS and SPMS are characterized by a neurodegenerative process leading to a neural death [16]. An immunosuppressive monoclonal antibody ocrelizumab is indicated for the treatment of PPMS; however, there is no licensed treatment for SPMS [18] (Table 1).

Table 1. Licensed disease-modifying drugs in multiple sclerosis. [19,20,21].

\begin{tabular}{ccc}
\hline Class & Drugs & Indications \\
& & $\begin{array}{c}\text { CIS } \\
\text { Active RRMS }\end{array}$ \\
\cline { 2 - 3 } & Interferon beta (IFN- $\beta$ ) & $\begin{array}{c}\text { acute flare-ups RRMS } \\
\text { Relapse prevention }\end{array}$ \\
\cline { 2 - 3 } Immunomodulators & Methylprednisolone & $\begin{array}{c}\text { CIS } \\
\text { Active RRMS }\end{array}$ \\
\cline { 2 - 3 } & Glatiramer acetate (GA) & Active RRMS \\
\cline { 2 - 3 } & Dimethyl fumarate & Active RRMS \\
& Fingolimod & Active RRMS \\
\cline { 2 - 3 } Immunosuppressors & Teriflunomide & Active RRMS \\
\cline { 2 - 3 } & Alemtuzumab & High-active RRMS \\
\cline { 2 - 3 } & Natalizumab & Active RRMS \\
\hline
\end{tabular}




\begin{tabular}{ccc}
\hline & & $\begin{array}{c}\text { High-active RRMS } \\
\text { PPMS }\end{array}$ \\
& & High-active RRMS \\
\cline { 2 - 3 } Cytotoxic Agents & Cladribine & High-active RRMS \\
\cline { 2 - 3 }
\end{tabular}

In addition to inflammation and neurodegeneration, disturbance of redox metabolism has been observed and plays a crucial role in pathogenesis of MS [22,23,24]. The serum proteomics revealed that ceruloplasmin, clusterin, apolipoprotein E, and complement C3 were up-regulated in RRMS patients compared with healthy controls. Vitamin D-binding protein showed a progressive trend of oxidation and the increased oxidation of apolipoprotein A-IV in progression from remission to relapse of MS [25]. CSF samples of patients in a remission stage of RRMS showed higher purine oxidation product uric acid, reduced antioxidant, and increased intrathecal synthesis of IgG [26]. The observations suggest the presence of redox metabolism disturbance and involvement of inflammatory process in RRMS. Furthermore, higher serum alpha $(\alpha)$-tocopherol levels were associated with reduced $\mathrm{T} 1$ gadolinium $\left(\mathrm{Gd}^{+}\right)$- enhancing lesions and subsequent $\mathrm{T} 2$ lesions in MRI of RRMS patients on IFN- $\beta$. [Karg E, Klivenyi P, Bencsik K]. Antioxidant glutathione (GSH) mapping showed lower glutathione (GSH) concentrations in the fronto-parietal region of patients suffered from PPMS and SPMS than RRMS and no significant difference between those of RRMS and controls. Thus, the oxidative stress in CNS was linked to neurodegeneration in progressive types of MS [27].

This review article reviewed components of redox homeostasis including various reactive chemical species, oxidative and antioxidative enzymes, and resulting degradation products that serve as evidence of biochemical assaults and tissue injuries under redox disequilibrium. Alternations of redox components in MS in general, phase-, and treatment-specific components were reviewed in search of potential diagnostic, prognostic, predictive, and/or therapeutic redox biomarkers. Finally, monitoring different redox components including oxidative, antioxidative and degradation products during the disease progression helps evaluate the redox status of MS, expediting building the most proper personalized treatment plans for MS patients.

\section{Oxidative Stress}

A reduction oxidation (redox) reaction is a type of chemical reaction that involves the transfer of electrons between two molecules. A pair of electrons transfers from a nucleophile to an electrophile, forming a new covalent bond. The redox reaction is common and vital to the basic function of life such as cellular respiration in which sugar is oxidized to release energy which is stored in ATP. Redox metabolisms constitute multiple metabolic pathways involved in the series of redox chemical reactions indispensable for sustaining life and, at same time, engaged in removal of electrophilic oxidative species and other harmful nucleophiles produced from different metabolic reactions. The dynamic activities range from a single electron transfer, enzyme reaction, chemical reaction cascade, to signaling in cells, tissues, organ systems, and whole organismal levels [28].

\subsection{Oxidative Stressors}

Oxidative stress is a state caused by an imbalance between the relative levels of production of reactive oxidizing metabolites and their elimination by the enzymatic or non-enzymatic antioxidants system. The oxidative state is induced by oxidative stressors either derived from xenobiotics outside of cells or produced from the activities of oxidative enzymes and essential cellular constituents [29] (Figure 1 (a)). Oxidative stressors are linked to several neurological diseases including Alzheimer's disease (AD), Parkinson's disease (PD), MS, depression, and amyotrophic lateral sclerosis [30,31,32]. 
(a) Oxidative Stressors

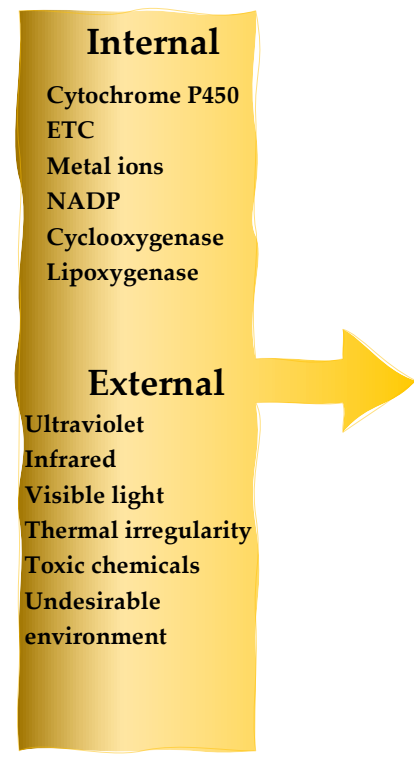

(b) Reductive Stressors

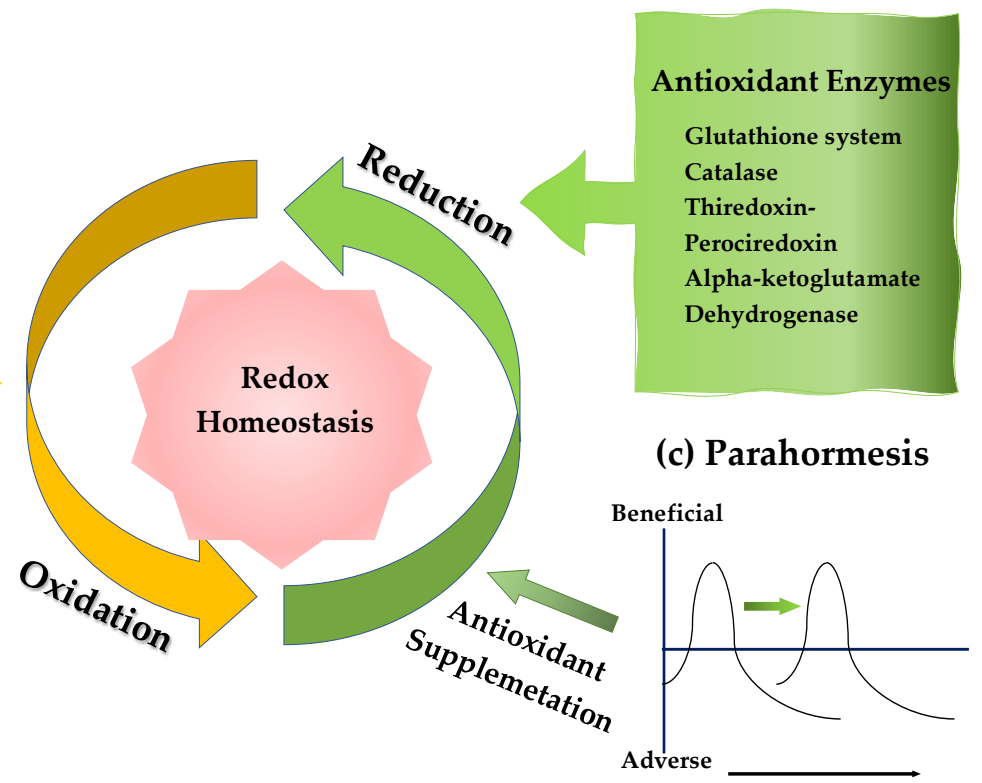

Figure 1. Redox homeostasis and antioxidant supplementation. (a) Oxidative stressors comprise of external and internal stressors, exerting oxidative chemical reactions in organism. Oxidation is an indispensable bioenergetic process to sustain life. (b). Reductive stressors are products of antioxidant enzymes that generate antioxidants in response to regular oxidation activity and increased oxidative stress. (c). Antioxidant supplementation attempts to shift the biphasic response from adverse to beneficial phase to maintain nucleophilic tone. This mechanism is called parahormesis.

\subsubsection{Endogenous oxidative stressors: oxidative enzymes and reactive species}

Endogenous oxidative stressors can be produced from cellular activities of cytosolic xanthine dehydrogenase (XDH), membrane-bound nicotinamide adenine dinucleotide phosphate (NADPH) oxidase, inflammatory lipoxygenase (LOX) and cyclooxygenase (COX), phagocytic myeloperoxidase (MPO) in respiratory burst, a second messenger nitrogen oxide (NO)-producing nitric oxide synthetase (NOS), mitochondrial and lysosomal electron transfer chain (ETC) enzymes, and among others. Transition metals such as iron $\left(\mathrm{Fe}^{2+}\right)$ and copper $\left(\mathrm{Cu}^{+}\right)$also play a crucial role in the formation of oxidative stressors via the Fenton reaction [33].

\subsubsection{Oxidative enzymes and reactive oxygen species}

Reactive oxygen species (ROS) include several free radicals such as superoxide $\left(\mathrm{O}_{2}^{-\bullet}\right)$ and hydroxyl radical $\left(\mathrm{OH}^{\bullet}\right)$ and nonradical molecules such as hydrogen peroxide $\left(\mathrm{H}_{2} \mathrm{O}_{2}\right)$ and organic hydroperoxide (ROOH) (Table 1). ROS are produced in endogenously in the cytosol, the plasma membrane, the membranes of mitochondria and endoplasmic reticulum, peroxisomes, and phagocytic cells [34] (Figure 2). ROS is difficult for direct measurement in biological tissues due to its highly reactivity and short life. 
Table 2. Reactive chemical species. During regular cellular activity living cells generate numerous chemical reactive species containing oxygen, nitrogen, sulfur, carbonyl, halogen, or selenium. Reactive sulfur species can contain thiols or nitrothiols. Free radicals possess at least one unpaired electron that makes highly reactive and short-lived. Nonradicals are oxidizing chemicals or easily converted to free radicals. Superoxide, reactive sulfur species, or reactive selenium species can be reducing agents as reactive nucleophilic species.

\begin{tabular}{|c|c|}
\hline & Reactive Chemical Species \\
\hline \multirow{2}{*}{ Reactive Oxygen Species (ROS) } & 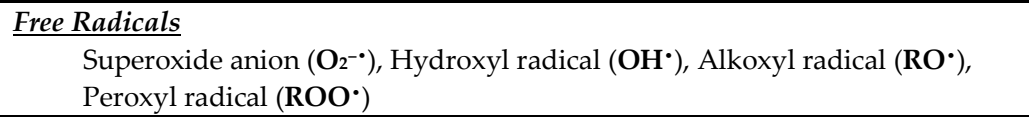 \\
\hline & $\begin{array}{l}\text { Nonradicals } \\
\text { Hydrogen peroxide }\left(\mathrm{H}_{2} \mathrm{O}_{2}\right) \text {, Organic hydroperoxide }(\mathrm{ROOH}), \\
\text { Organic peroxide }(\mathrm{ROOR}) \text {, Singlet oxygen }\left(\mathrm{O}_{2}{ }^{1} \Delta_{\mathrm{g}}\right) \text {, Ozone }\left(\mathrm{O}_{3}\right)\end{array}$ \\
\hline \multirow[b]{2}{*}{ Reactive Nitrogen Species (RNS) } & $\frac{\text { Free Radicals }}{\text { Nitric oxide radical (NO*), Nitrogen dioxide radical }\left(\mathrm{NO}_{2}{ }^{*}\right)}$ \\
\hline & $\begin{array}{l}\text { Nonradicals } \\
\text { Nitrite }\left(\mathrm{NO}_{2}^{-}\right) \text {, Nitrate }\left(\mathrm{NO}_{3}^{-}\right) \text {, Nitroxyl anion }\left(\mathrm{NO}^{-}\right) \text {, Nitrosyl cation }\left(\mathrm{NO}^{+}\right) \text {, } \\
\text { Peroxynitrite }\left(\mathrm{ONOO}^{-}\right) \text {, Peroxynitrate }\left(\mathrm{O}_{2} \mathrm{NOO}^{-}\right) \text {, } \\
\text { Nitrosoperoxycarbonate }\left(\mathrm{ONOOCO}_{2}^{-}\right) \text {, Dinitrogen trioxide }\left(\mathrm{N}_{2} \mathrm{O}_{3}\right) \text {, } \\
\text { Dinitrogen tetraoxide }\left(\mathrm{N}_{2} \mathrm{O}_{4}\right) \text {, Nitryl chloride }\left(\mathrm{NClO}_{2}\right)\end{array}$ \\
\hline \multirow[b]{2}{*}{ Reactive Sulfur Species (RSN) } & $\begin{array}{l}\frac{\text { Free radicals }}{\text { Thiyl radical }(\text { RS·), Peroxysulphenyl radical (RSOO•) }} \\
\text { P. }\end{array}$ \\
\hline & 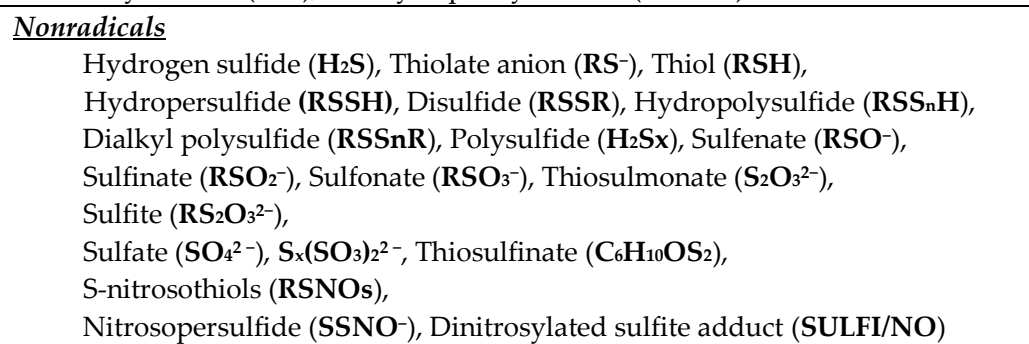 \\
\hline Reactive Carbonyl Species (RCS) & $\begin{array}{l}\text { Nonradicals } \\
\left.\text { Acetaldehyde }\left(\mathrm{CH}_{3} \mathrm{CHO}\right) \text {, Acrolein (Proponel }{ }^{+}: \mathrm{C}_{3} \mathrm{H}_{4} \mathrm{O}\right), \\
\text { Methylglyoxal 4-Hydroxy-nonenal }\left(\mathrm{C}_{9} \mathrm{H}_{16} \mathrm{O}_{2}\right), 3 \text {-Deoxyglucosone }\left(\mathrm{C}_{6} \mathrm{H}_{10} \mathrm{O}_{5}\right) \text {, } \\
\text { Glyoxal }\left(\mathrm{C}_{2} \mathrm{H}_{2} \mathrm{O}_{2}\right) \text {, Methylgyoxal }\left(\mathrm{C}_{3} \mathrm{H}_{4} \mathrm{O}_{2}\right), \\
\text { Electronically excited (triplet) carbonyls }\left({ }^{3} \mathrm{~L}^{2} \mathrm{O}^{*}\right)\end{array}$ \\
\hline \multirow[b]{2}{*}{ Reactive Halogen species (RHS) } & $\begin{array}{l}\frac{\text { Free radicals }}{\text { Atomic chlorine }\left(\mathrm{Cl}^{*}\right) \text {, Atomic bromine }\left(\mathrm{Br}^{*}\right)} \\
\text {. }\end{array}$ \\
\hline & $\begin{array}{l}\text { Nonradicals } \\
\text { Hypochlorite }\left(\mathrm{OCl}^{-}\right) \text {, Chloramines }\left(\mathrm{RNHCl}^{-}, \text {Hypobromite }\left(\mathrm{OBr}^{-}\right) \text {, }\right. \\
\text { Hypoiodite }\left(\mathrm{IO}^{-}\right), \text {Hypohalogenite }\left(\mathrm{XO}^{-} ; \mathbf{X}=\mathbf{F}, \mathbf{C l}, \mathbf{B r} \text {, or } \mathbf{I}\right)\end{array}$ \\
\hline Reactive Selenium Species (RSeS) & $\begin{array}{l}\text { Nonradicals } \\
\begin{array}{l}\text { Selenite }\left(\mathrm{O}_{3} \mathrm{Se}^{-2}\right) \text {, Selenate }\left(\mathrm{SeO}_{4}{ }^{2-}\right) \text {, Selenocysteine }\left(\mathrm{C}_{3} \mathrm{H}_{7} \mathrm{NO}_{2} \mathrm{Se}\right) \text {, } \\
\text { Selenomethionine }\left(\mathrm{C}_{5} \mathrm{H}_{11} \mathrm{NO}_{2} \mathrm{Se}\right)\end{array}\end{array}$ \\
\hline \multirow[b]{2}{*}{ Reactive Nucleophilic Species } & $\frac{\text { Free radicals }}{\text { Superoxide }\left(\mathrm{O}_{2}^{-\cdot}\right)}$ \\
\hline & $\begin{array}{l}\text { Noneradicals } \\
\text { Hydrogen sulfide }\left(\mathrm{H}_{2} \mathrm{~S}\right) \text {, Thiolate }\left(\mathrm{RS}^{-}\right) \text {, Hydropersulfide (RSS-), Disulfide } \\
\text { (RSSR), } \\
\text { Selenite }\left(\mathrm{O}_{3} \mathrm{Se}^{-2}\right) \text {, Selenate }\left(\mathrm{SeO}_{4}{ }^{2-}\right) \text {, Selenocysteine }\left(\mathrm{C}_{3} \mathrm{H}_{7} \mathrm{NO}_{2} \mathrm{Se}\right) \text {, } \\
\text { Selenomethionine }\left(\mathrm{C}_{5} \mathrm{H}_{11} \mathrm{NO}_{2} \mathrm{Se}\right)\end{array}$ \\
\hline
\end{tabular}




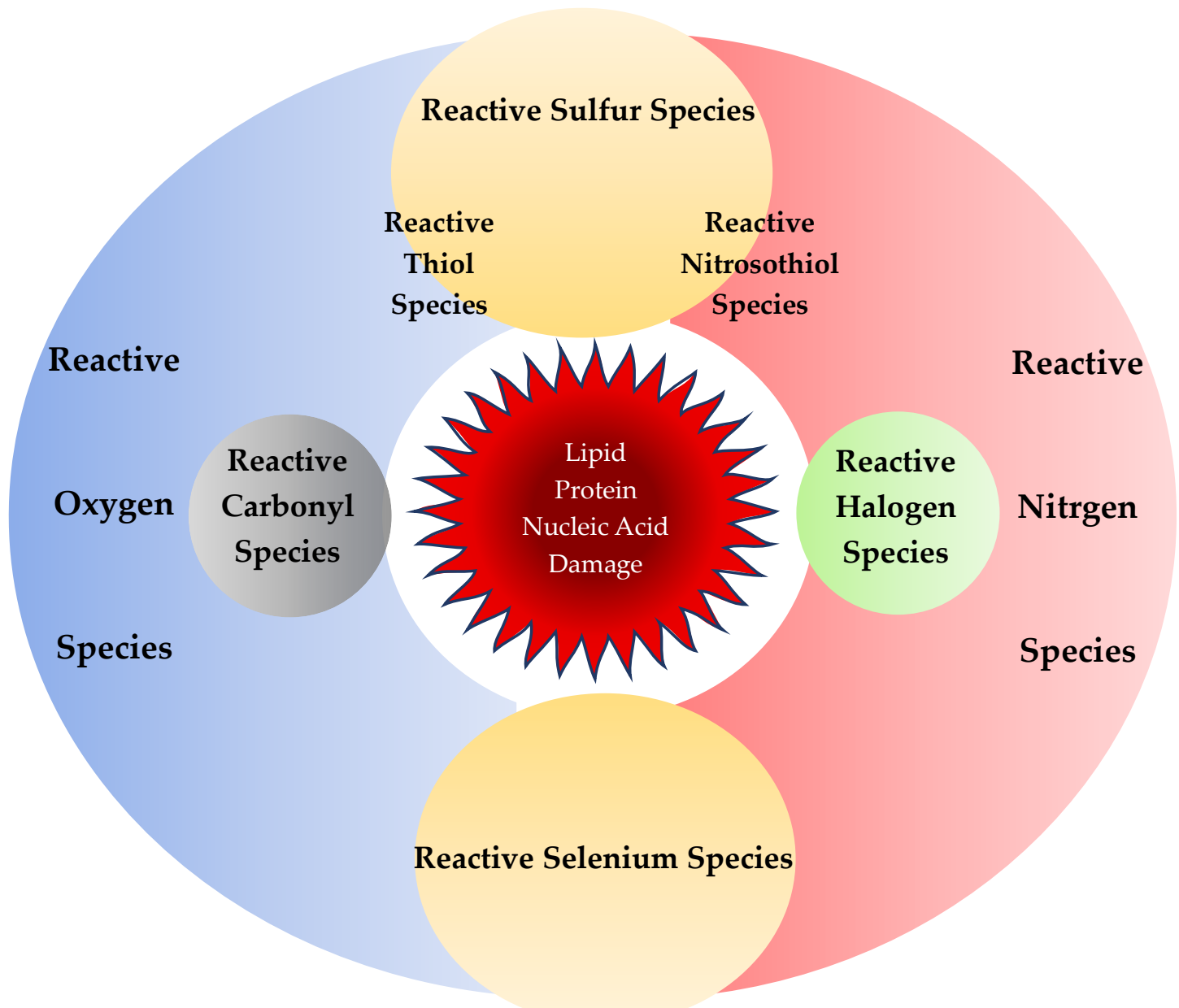

Figure 2. Reactive Chemical Species. Reactive chemical species comprise of not only reactive oxygen and nitrogen species, but also reactive sulfur, carbonyl, halogen, and selenium species. Sulfur reacts with oxygen or nitrogen to form reactive thiol or nitrosothiol species, respectively. All reactive chemical species react in concert during regular cellular activity but may cause oxidative stress to damage cellular components such as proteins, lipids, and nucleic acids.

In the cytosol, ROS can be generated by soluble intercellular components such as catecholamines, hydroquinones, flavins and thiols (RSHs) which undergo reduction reactions [35]. The cytosolic enzyme XDH normally catalyzes xanthine, nicotinamide adenine dinucleotide (NAD $\left.{ }^{+}\right)$ and water $\left(\mathrm{H}_{2} \mathrm{O}\right)$ to urate, reduced form of $\mathrm{NAD}^{+}, \mathrm{NADH}$ and hydrogen ion $\left(\mathrm{H}^{+}\right)$. Reversible oxidation of cysteine residues or irreversible $\mathrm{Ca}^{2+}$-stimulated proteolysis converts $\mathrm{XDH}$ to xanthine oxidase $(\mathrm{XO})$ that transfers electrons to molecular oxygen $\left(\mathrm{O}_{2}\right)$, producing superoxide $\left(\mathrm{O}_{2}{ }^{-} \cdot\right)$ during xanthine or hypoxanthine oxidation [36]. The serum levels of uric acid, a major endogenous antioxidant was measured in patients with PPMM, RRMM, and SPMM. The uric acid levels were significantly lower in active MS than inactive MS, and the uric acid levels were independently correlated with gender, disease activity and duration of the disease [37]. The expression and activity of $\mathrm{XO}$ were significantly increased in experimental autoimmune encephalomyelitis (EAE), an animal model of MS, compared to naïve mouse. The increased XO was reversed with the treatment of XO inhibitor, febuxostat [38] (Table 3). 
Table 3. Oxidative stress biomarkers of multiple sclerosis. The redox status can be monitored by the activities of oxidative and antioxidative enzymes and degradation products derived from cellular proteins, amino acids, lipids, and/or nucleic acids. $\uparrow$ : increase, $\downarrow$ : decrease, -: unknown. EAE: experimental autoimmune encephalomyelitis, Theiler's murine encephalomyelitis virus (TMEV)

\begin{tabular}{|c|c|c|c|c|c|c|}
\hline \multicolumn{2}{|c|}{ Classes } & Types & Blood & CSF & Others & Reference \\
\hline \multicolumn{2}{|c|}{ Reactive Species } & Reactive Nitrogen Species & $\uparrow$ & $\uparrow$ & - & [69] \\
\hline \multirow{10}{*}{\multicolumn{2}{|c|}{ Oxidative Enzymes }} & Xanthine Dehydrogenase (XHD) & $\downarrow$ & - & - & \\
\hline & & Xanthine Oxidase $(\mathrm{XO})$ & - & - & $\uparrow \mathrm{EAE}$ & [38] \\
\hline & & Nicotinamide Adenine Dinucleotide & $\uparrow \downarrow$ & & Isoform & [39] \\
\hline & & Phosphate (NADPH) Oxidase & $1 \downarrow$ & & dependent & \\
\hline & & & & & $\uparrow$ Brain & [43] \\
\hline & & Cyclooxygenase (COX) & - & - & $\begin{array}{l}\text { tissue, } \uparrow \\
\text { EAE, } \\
\uparrow \mathrm{TMEV}\end{array}$ & \\
\hline & & Lipoxygenase (LOX) & - & - & $\begin{array}{l}\uparrow \text { plaques, } \uparrow \\
\text { EAE }\end{array}$ & [43] \\
\hline & & Superoxide Dismutase (SOD) & $\uparrow$ & $\downarrow$ & - & {$[53.54 .55,56]$} \\
\hline & & $\begin{array}{l}\text { Inducible Nitric Oxide Synthase } \\
\text { (iNOS) }\end{array}$ & $\uparrow$ & $\uparrow$ & $\uparrow \mathrm{EAE}$ & {$[16,84,85,86]$} \\
\hline & & Myeloperoxidase (MPO) & mixed & $?$ & - & [40] \\
\hline \multirow{7}{*}{\multicolumn{2}{|c|}{$\begin{array}{l}\text { Antioxidative Enzymes } \\
\text { and } \\
\text { Transcriptional Factors }\end{array}$}} & Glutathione Peroxidase (GPx) & $\uparrow$ (relapse) & $\downarrow$ & - & {$[112,123,124,126$} \\
\hline & & Glutathione Reductase (GSR) & $\begin{array}{c}\downarrow(\text { remission }) \\
-\end{array}$ & $\uparrow$ & - & $\begin{array}{l}12,120] \\
{[128,129]}\end{array}$ \\
\hline & & Catalase & $\begin{array}{c}\downarrow \\
\text { (granulocyte) }\end{array}$ & $?$ & - & {$[131,132]$} \\
\hline & & Xanthine oxidase (XO)-Uric Acid & $\downarrow$ & - & - & {$[37,38$} \\
\hline & & $\begin{array}{l}\text { Nuclear Factor Erythroid 2-Related } \\
\text { Factor (Nrf2) }\end{array}$ & $\uparrow$ & - & - & {$[56]$} \\
\hline & & $\begin{array}{l}\text { Peroxisome proliferator-activated } \\
\text { receptors (PPARs) }\end{array}$ & - & $\uparrow$ & - & {$[140]$} \\
\hline & & $\begin{array}{l}\text { Peroxisome proliferator-activated } \\
\text { receptor gamma coactivator 1-alpha } \\
(\text { PGC-1 } \alpha)\end{array}$ & $\downarrow$ & - & - & [142] \\
\hline \multirow{13}{*}{$\begin{array}{l}\text { Degradation } \\
\text { Products } \\
\text { and } \\
\text { End Products }\end{array}$} & \multirow{6}{*}{ Protein } & Protein carbonyls & $\uparrow$ & - & - & $\begin{array}{l}{[148,149,150,156} \\
, 157,158,159]\end{array}$ \\
\hline & & 3-nitrotyrosin (3-NO-Tyr) & $\uparrow$ & - & - & $\begin{array}{l}{[155,156,157,158} \\
, 159]\end{array}$ \\
\hline & & Protein glutathionylation & $?$ & - & - & {$[161]$} \\
\hline & & Dityrosine & $\uparrow$ & - & - & {$[152]$} \\
\hline & & $\begin{array}{l}\text { Advanced oxidation protein } \\
\text { products (AOPPs) }\end{array}$ & $\uparrow$ & - & - & {$[53,152,163]$} \\
\hline & & $\begin{array}{l}\text { Advanced glycation protein products } \\
\text { (AGPPs) }\end{array}$ & $\uparrow$ & $\uparrow$ & - & {$[152,165]$} \\
\hline & $\begin{array}{l}\text { Amino } \\
\text { acids }\end{array}$ & $\begin{array}{l}\text { Asymmetric dimethylarginine } \\
\text { (ADMA) }\end{array}$ & $\downarrow$ & - & - & [167] \\
\hline & \multirow{5}{*}{ Lipid } & F2-isoprostane (F2-isoP) & $\uparrow$ & $\uparrow$ & - & $\begin{array}{l}{[169,170,171,172} \\
, 173]\end{array}$ \\
\hline & & Malondialdehyde (MDA) & mixed & $\uparrow$ & - & $\begin{array}{l}{[52,70,128,} \\
132,174]\end{array}$ \\
\hline & & 4-hydroxynonenal (4-HNE) & $?$ & $\uparrow$ & - & {$[175]$} \\
\hline & & $\begin{array}{l}\text { Hydroxyoctadecadienoic acid } \\
\text { (HODE) }\end{array}$ & $\uparrow$ & $\uparrow$ & - & [176] \\
\hline & & Oxysterol & $\uparrow$ or $\downarrow$ & $\uparrow$ & - & [178] \\
\hline & DNA & $\begin{array}{l}\text { 8-dihydro-2'deoxyguanosine (8- } \\
\text { oxodG) }\end{array}$ & $\uparrow$ & $?$ & - & [112] \\
\hline
\end{tabular}

The plasma membrane is a network of phospholipid bilayer and integral proteins, which protects the cellular organelles from the outer environment and responsible for several cellular functions such as cell adhesion, ion transport, cell signaling and phagocytosis. The main ROS of the plasma membrane is superoxide $\left(\mathrm{O}_{2}{ }^{-}\right)$produced by the membrane-bound enzyme nicotinamide adenine dinucleotide phosphate oxidase (NOX) which is composed of two membrane proteins, three 
cytosolic proteins, and a small GTP-binding protein [39]. The expression of NOX isoform NOX5 was significantly increased, but the expression NOX4 was significantly decreased in serum of RRMS patients, suggesting differential NOX isoform expression contributes to OS-associated vascular changes in MS [40]. ROS is also produced by COX and LOX which convert arachidonic acid to prostaglandins, thromboxanes, and leukotrienes. Phospholipase $\mathrm{A}_{2}$ generates ROS during arachidonic acid oxidation [41]. In the presence of transition metal ions such as $\mathrm{Fe}^{2+}$ and $\mathrm{Cu}^{+}$, hydrogen peroxide $\left(\mathrm{H}_{2} \mathrm{O}_{2}\right)$, organic hydroperoxide $(\mathrm{ROOH})$ and organic peroxide (ROOR) produce hydroxyl $\left(\mathrm{OH}^{\bullet}\right)$, alkoxyl $\left(\mathrm{RO}^{*}\right)$ and peroxyl radical $(\mathrm{ROO} \cdot)$, respectively [42]. COX2 was observed expressed in the brain tissue of MS patients and Theiler's murine encephalomyelitis virus (TMEV) model. 5-fold increase of COX2 mRNA was detected in experimental autoimmune encephalomyelitis (EAE) model of MS. LOX5, 12 and 15 were increased 8- to 10-fold in EAE model of MS [43] (Table 3).

Superoxide dismutase (SOD) catalyzes the disproportionation of two superoxide $\left(\mathrm{O}_{2}^{-\bullet}\right)$ into molecular oxygen $\left(\mathrm{O}_{2}\right)$ and hydrogen peroxide $\left(\mathrm{H}_{2} \mathrm{O}_{2}\right)$. These enzymes are present in almost all aerobic cells and in extracellular fluids. SODs contain metal ion cofactors that, depending on the isozyme, can be copper, zinc, manganese, or iron [44]. There are three isozymes in humans. Dimeric copper- and zinc-coordinated SOD1 is in the cytoplasm; tetrameric manganese-coordinated SOD2 is confined to the mitochondria; tetrameric copper- and zinc-coordinated SOD3 is extracellular [45]. The mitochondrial ROS production takes place at four protein complexes, ubiquinone, and cytochrome $\mathrm{c}$ of the ETC, embedded in the inner membrane of the mitochondria [46]. The Complexes I/III/IV utilize $\mathrm{NADH}$ as the substrate, while Complexes II/III/IV use succinic acid. The complex II is also glycerol 3-phosphate dependent. The primary mitochondrial ROS is superoxide $\left(\mathrm{O}_{2}^{-\bullet}\right)$ that is converted by mitochondrial SOD into hydrogen peroxide $\left(\mathrm{H}_{2} \mathrm{O}_{2}\right)$, which can be turned into hydroxyl $\left(\mathrm{OH}^{*}\right)$ via the Fenton reaction [47]. The Complex I and III release superoxide $\left(\mathrm{O}_{2}^{-\bullet}\right)$ into the mitochondrial matrix where it can damage the mitochondrial DNA, while the Complex III also releases superoxide $\left(\mathrm{O}_{2}^{-\bullet}\right)$ into the intermembrane space where it is accessible to the cytosol [48]. Reduced levels of antioxidant $\alpha$-tocopherol was observed in blood of patients with Leber's hereditary optic neuropathy which is caused by mitochondrial mutation of the Complex I, suggesting that oxidative load was elevated, and antioxidant capacity was compromised [49]. Other mitochondrial enzymes which contribute to hydrogen peroxide $\left(\mathrm{H}_{2} \mathrm{O}_{2}\right)$ production are monoamine oxidases, dihydroorotate dehydrogenase, $\alpha$ glycerophosphate dehydrogenase and $\alpha$-ketoglutarate dehydrogenase $(\alpha-\mathrm{KGDH})$ complex. Succinate dehydrogenase also generate ROS [50].

Significantly higher mean activity of SOD in erythrocyte lysates was reported in RRMS than controls. Interestingly, the SOD activity of CIS was higher than that of RRMS [51]. The SOD activity was significantly lower in the erythrocyte lysates of RRSM patients upon relapse than controls but increased following the intravenous administration of corticosteroid methylprednisolone and remained higher during remission period than controls. The mean SOD activity of serum/plasma samples was significantly higher in RRMS compared to control groups [52]. However, platelet SOD1 and SOD2 activity was unchanged in MS patients [53]. In contrast SOD activity was observed significant low in CSF of CIS and RRMS patients despite significantly high activity of plasma SOD. There were negative correlations between the erythrocyte SOD activity and disease duration and expanded disability status scale (EDSS) in CIS and RRMS, between the erythrocyte SOD activity and gadolinium enhancement lesion volume $\left(\mathrm{Gd}^{+}\right)$in CIS patients [54]. These findings suggest SOD activity as possible diagnostic and prognostic marker (Tanble 3, Table 4). 
Table 4. Possible redox biomarkers in multiple sclerosis. Reactive chemical species, oxidative enzymes, antioxidants, antioxidative enzymes, degradation products, and end products are potential biomarkers for multiple sclerosis. Diagnostic biomarkers allow early detection and secondary prevention; prognostic biomarkers suggest the likely clinical course; predictive biomarkers predict the response of MS patients to a specific therapy; and therapeutic biomarkers indicate a target for therapy. CIS: clinically isolated syndrome, PPMS: primary progressive multiple sclerosis; RRMS: relapsing-remitting multiple sclerosis, SPMS: secondary progressive multiple sclerosis, mixedMM: mixed population of multiple sclerosis.

\begin{tabular}{|c|c|c|c|c|c|}
\hline \multirow[t]{2}{*}{ Class } & \multirow[t]{2}{*}{ Components } & \multicolumn{4}{|c|}{ Biomarkers } \\
\hline & & Diagnostic & Prognostic & Predictive & Therapeutic \\
\hline $\begin{array}{l}\text { Reactive } \\
\text { Chemical } \\
\text { Species }\end{array}$ & $\begin{array}{l}\text { Total nitrite }\left(\mathrm{NO}_{2}^{-}\right) / \text {nitrite } \\
\left(\mathrm{NO}_{3}^{-}\right) \text {value }(\mathrm{tNOx}) \\
\text { S-nitrosothiol }\end{array}$ & $\begin{array}{l}\text { PPMS, RRMS, } \\
\text { Relaps, SPMS } \\
\text { RRMS, SPMS }\end{array}$ & $\begin{array}{c}\text { RRMS } \\
\text { Spinal injury }\end{array}$ & - & - \\
\hline $\begin{array}{l}\text { Oxidative } \\
\text { Enzymes }\end{array}$ & $\begin{array}{l}\text { Superoxide dismutase (SOD) } \\
\text { Myeloperoxidase (MPO) } \\
\text { Inducible nitric oxide synthase } \\
\text { (iNOS) }\end{array}$ & $\begin{array}{l}\text { CIS, RRMS } \\
\text { RRMS } \\
\text { RRMS }\end{array}$ & $\begin{array}{l}\text { CIS, RRMS } \\
\text { RRMS } \\
-\end{array}$ & $\begin{array}{c}\text { RRMS } \\
- \\
-\end{array}$ & $\begin{array}{c}\text { RRMS } \\
- \\
-\end{array}$ \\
\hline $\begin{array}{l}\text { Antioxidants, } \\
\text { Antioxidative } \\
\text { Enzymes }\end{array}$ & $\begin{array}{l}\text { xanthine oxidase (XO)-Uric } \\
\text { Acid } \\
\text { Selenium } \\
\text { glutathione reductase (GSR) } \\
\text { catalase } \\
\text { Thioredoxin-peroxiredoxin } \\
\text { (TRX-PRDX) } \\
\text { Nuclear factor erythroid 2- } \\
\text { related factor (Nrf2) } \\
\text { Peroxisome proliferator- } \\
\text { activated receptors (PPARs) } \\
\text { Peroxisome proliferator- } \\
\text { activated receptor gamma } \\
\text { coactivator 1-alpha (PGC-1 } \alpha \text { ) }\end{array}$ & $\begin{array}{c}\text { PPMM, } \\
\text { RRMM, } \\
\text { SPMM } \\
\text { RRMS } \\
\text { mixedMM } \\
\text { CIS, RRMS } \\
\text { MS } \\
\text { RRMS } \\
\text { RRMS }\end{array}$ & $\begin{array}{c}- \\
\text { - } \\
\text { MixedMM } \\
\text { RRMS } \\
- \\
- \\
- \\
-\end{array}$ & $\begin{array}{c}- \\
- \\
- \\
- \\
\text { RRMS } \\
-\end{array}$ & $\begin{array}{l}- \\
- \\
- \\
- \\
-\end{array}$ \\
\hline $\begin{array}{l}\text { Degradation } \\
\text { Products } \\
\text { and } \\
\text { End Products }\end{array}$ & $\begin{array}{l}\text { Protein carbonyls } \\
\text { 3-nitrotyrosine (3-NO-Tyr) } \\
\text { Glutathionylation } \\
\text { Dityrosine } \\
\text { Advanced oxidation protein } \\
\text { products (AOPPs) } \\
\text { Advanced glycation End } \\
\text { products (AGEs) } \\
\text { Asymmetric } \\
\text { dimethylarginine (ADMA) } \\
\text { F2-isoprostane (F2-isoP) } \\
\text { Malondialdehyde (MDA) } \\
\text { 4-hydroxynonenal (4-HNE) } \\
\text { Hydroxyoctadecadienoic acid } \\
\text { (HODE) } \\
\text { Oxocholesterols } \\
\text { Oxidized low-density } \\
\text { lipoprotein (oxLDL) } \\
\text { 8-OH2dG }\end{array}$ & $\begin{array}{c}\text { RRMS, SPMS } \\
\text { RRMS, SPMS } \\
\text { Acute attack } \\
\text { RRSM } \\
\text { CIS, RRMS } \\
\text { RRMS } \\
\text { RRMS, SPMS } \\
\text { RRMS, SPMS } \\
\text { RRMS } \\
\text { PPMS, RRMS, } \\
\text { SPMS } \\
\text { CIS, RRMS } \\
\text { MixedMS } \\
\text { RRMS, SPMS }\end{array}$ & $\begin{array}{c}\text { RRMS, SPMS } \\
- \\
- \\
\text { - } \\
\text { RRMS } \\
- \\
\text { - } \\
\text { SPMS } \\
\text { RRMS } \\
\text { - } \\
\text { - } \\
\text { SPMS } \\
\text { - }\end{array}$ & $\begin{array}{c}\text { RRMS } \\
\text { RRMS } \\
- \\
- \\
\text { RRMS } \\
- \\
- \\
\text { RRMS } \\
- \\
- \\
- \\
-\end{array}$ & $\begin{array}{l}- \\
- \\
- \\
- \\
- \\
-\end{array}$ \\
\hline
\end{tabular}


The peripheral blood mononuclear cells (PBMCs) SOD1 proteins and mRNA expression were significantly lower in RRMS patients than controls and became significantly elevated following IFN$\beta 1 \mathrm{~b}$ treatment than the baseline [55]. These studies suggest SOD as a potential therapeutic biomarker (Table 4). However, the erythrocyte SOD activity remained unchanged following the treatment of natalizumab, a humanized monoclonal antibody against the cell adhesion molecule $\alpha 4$-integrin. But levels of carbonylated protein and oxidized guanosine were reduced [56].

In the inner membrane of mitochondria and the endoplasmic reticulum, a heme-containing monooxygenase cytochrome P450 (CYP) enzymes are responsible for oxidizing steroids, cholesterols, and fatty acids. The CYPs forms ROS superoxide $\left(\mathrm{O}_{2}^{-\bullet}\right)$ and hydrogen peroxide $(\mathrm{ROOH})$ by substrate cycling [57]. Protonation of hydrogen peroxide (ROOH) forms hydrogen peroxide $\left(\mathrm{H}_{2} \mathrm{O}_{2}\right)$ which, furthermore, cleaves into hydroxy radicals $\left(\mathrm{OH}^{\bullet}\right)$. The redox cycling produces free radical semiquinone from quinoid substrates [58]. In the mitochondrial transport chain, flavoprotein reductase forms ROS by direct reduction of $\mathrm{O}_{2}$ and via the mediation of quinones. [59]. Superoxide $\left(\mathrm{O}_{2}^{-\bullet}\right)$ is produced by $\mathrm{XO}$ in the reperfusion phase of ischemia, LOX, COX, and NADPH-dependent oxidase [60]. In the endoplasmic reticulum NADH cytochrome b5 reductase can leak electrons to molecular oxygen $\left(\mathrm{O}_{2}\right)$ to generate superoxide $\left(\mathrm{O}_{2}^{-\bullet}\right)$ during the NADPH-dependent oxidation of xenobiotics [61].

Most enzymes in the peroxisomes produce ROS during the catalysis of fatty acid $\alpha$ - and $\beta$ oxidation, amino acid and glyoxylate metabolism, and synthesis of lipidic compounds. A large fraction of hydrogen peroxide $\left(\mathrm{H}_{2} \mathrm{O}_{2}\right)$ generated inside peroxisomes was observed to penetrate the peroxisomal membrane and diffuse to the surrounding media [62]. The peroxide can diffuse through the channel formed by the peroxisomal membrane protein Pxmp2 and hydrogen peroxide $\left(\mathrm{H}_{2} \mathrm{O}_{2}\right)$ generated by the peroxisomal urate oxidase can release through crystalloid core tubules into the cytosol [63]. Meanwhile, peroxisomes also possess protective mechanisms to counteract oxidative stress and maintain redox balance. Reduction in peroxisomal gene and protein expression was observed in MS grey matter [64].

The lysosomal ETC plays a central role to support the positive proton gradient to maintain an optimal $\mathrm{pH}$ of the acid hydrolases [65]. The ETC is made up of a flavin-adenine dinucleotide (FAD), a b-type cytochrome and ubiquinone with the donor $\mathrm{NADH}$ and ending to acceptor molecular oxygen $\left(\mathrm{O}_{2}\right)$, transferring three electrons. Superoxide $\left(\mathrm{O}_{2^{-} \cdot}\right)$ is possibly produced in the acidic environment which favors dismutation of hydrogen peroxide $\left(\mathrm{H}_{2} \mathrm{O}_{2}\right)$ into hydroxy radical $\left(\mathrm{OH}^{\bullet}\right)$ by ferrous iron [66]. Furthermore, ozone $\left(\mathrm{O}_{3}\right)$ and ozone-like oxidants are generated from singlet oxygen $\left(\mathrm{O}_{2}{ }^{1} \Delta_{\mathrm{g}}\right)$ catalyzed by antibody or amino acid. Ozone $\left(\mathrm{O}_{3}\right)$ reacts with superoxide anion $\left(\mathrm{O}_{2}^{-\bullet}\right)$ to form hydrogen peroxide $\left(\mathrm{H}_{2} \mathrm{O}_{2}\right)$ in the presence of $\mathrm{Fe}^{+2}$ [67].

\subsubsection{Oxidative enzymes and reactive nitrogen species}

Reactive nitrogen species (RNS) are a group of nitrogen-congaing molecules including free radicals, nitric oxide $(\mathrm{NO})$, and nitrogen dioxide $\left(\mathrm{NO}_{2}\right)$. Free radicals are nitric oxide $\left(\mathrm{NO}^{*}\right)$ and nitrogen dioxide $\left(\mathrm{NO}_{2}{ }^{-}\right)$radicals, while nonradicals are nitrite $\left(\mathrm{NO}_{2}^{-}\right)$, nitrate $\left(\mathrm{NO}_{3}{ }^{-}\right)$, among others (Table 2). RNS are derived from nitric oxide $(\mathrm{NO})$ and superoxide anion $\left(\mathrm{O}_{2}^{-\bullet}\right)$ produced by nitric oxide synthetase 2 (NOS2), NADPH oxidase, XO, LOX, COX, among others [68]. At physiological concentrations, a gaseous molecule nitric oxide (NO) is a second messenger involved in blood pressure regulation, smooth muscle relaxation, defense mechanisms, immune regulation, and neurotransmission contributing the function of memory and learning [69].

Cross-sectional studies showed that the levels of nitric oxide metabolites nitrite $\left(\mathrm{NO}_{2}{ }^{-}\right)$and nitrite $\left(\mathrm{NO}_{3}{ }^{-}\right)$, measured as a total value (tNOx) are significant higher in plasma or serum of patients with RRMS [70,71]. A longitudinal study revealed that higher serum tNOx is significantly correlated with relapsing rate, suggesting prognostic biomarker of NOS [72]. Many studies of CSF samples reported significantly higher levels of tNOx in RRMS and PPMS, compared to healthy controls [73,74]. A study observed significantly higher levels of CSF tNOx in RRMS than SPMS, suggesting an inflammatory role of RNS [75]. Significantly higher levels of CSF tNOx were reported in patients with acute relapsing phase of RRMS than those with stable remitting phase of RRMS [76,77] (Table 3, Table 4). 
In cGMP-dependent pathways, nitric oxide radical (NO•) generated by endothelial NOS in endothelium, brain, and heart relaxes blood vessels and maintains normal blood pressure, while nitric oxide radicals $\left(\mathrm{NO}^{*}\right)$ produced by neuronal NOS serve as a neurotransmitter to regulate blood pressure in the brain. Inducible NOS ( $i$ NOS) in macrophages and smooth muscle cells gives rise to nitric oxide radicals (NO•) as in reaction to bacterial lipopolysaccharides and/or cytokines [78].

Nitric oxide radical $\left(\mathrm{NO}^{*}\right)$ is produced from the metabolism of L-arginine by NOS that converts L-arginine into L-citrulline and nitric oxide radical $(\mathrm{NO} \cdot)$ by a 5-electron oxidation of a guanidine nitrogen of L-arginine [79]. In mitochondria nitric oxide radicals (NO*) react with respiratory Complex III to inhibit electron transfer and facilitate superoxide anion $\left(\mathrm{O}_{2}{ }^{--}\right)$production. The nitric oxide radicals $\left(\mathrm{NO}^{*}\right)$ also compete with molecular oxygen $\left(\mathrm{O}_{2}\right)$ for the binding site at the binuclear center of cytochrome $c$ oxidoreductase, inducing a reversible inhibition of cytochrome $c$ oxidase. Nitric oxide (NO) neutralizes ROS [36]. However, RNS react with oxygen molecules $\left(\mathrm{O}_{2}\right)$ and $\mathrm{ROS}$, giving rise to a variety of nitrogen oxides such as nitrogen dioxide radical $\left(\mathrm{NO}_{2}{ }^{\bullet}\right)$, nitrogen dioxide $\left(\mathrm{NO}_{2}\right)$, dinitrogen trioxide $\left(\mathrm{N}_{2} \mathrm{O}_{3}\right)$, peroxynitrite $\left(\mathrm{ONOO}^{-}\right)$, nitrite $\left(\mathrm{NO}_{2}{ }^{-}\right)$, and nitrate $\left(\mathrm{NO}_{3}{ }^{-}\right)$. Higher concentrations of nitric oxide (NO) become toxic by forming nitrosothiols which oxidize tyrosine, cysteine, methionine, and glutathione (GSH). In mitochondria, nitric oxide radicals (NO•) inhibit Complex I by $S$-nitrosation [80]. Together with other RNS this contributes the damage of cell membranes, proteins, and lipid membrane leading to the degradation of mitochondria, lysosomes, and DNA. The chain of events culminates in the inhibition of immune response and production of carcinogenic nitrosamines [81]. Nitric oxide (NO) is also involved in metal homeostasis including Fe, $\mathrm{Cu}$, and $\mathrm{Zn}[82]$.

Highly toxic peroxynitrite $\left(\mathrm{ONOO}^{-}\right)$is formed by the reaction of nitric oxide (NO) and superoxide anions $\left(\mathrm{O}_{2}^{-\bullet}\right)$ leading to the production of more reactive compounds that oxidize methionine and tyrosine residues of proteins, lipids, and DNA. Reacting with superoxide anion $\left(\mathrm{O}_{2}{ }^{\bullet}\right)$, nitric oxide radicals $(\mathrm{NO} \cdot)$ form peroxynitrite which causes reversible inhibition of cellular respiration in the mitochondria [83]. In peroxisomes nitric oxide radicals (NO•) react with superoxide anions $\left(\mathrm{O}_{2}^{-\bullet}\right)$ produced by $\mathrm{XO}$ to form peroxynitrite and hydrogen peroxides [63].

In response to bacterial lipopolysaccharides and inflammatory stimuli, $i$ NOS generates nitric oxide (NO) that protects tissue hypoxia and serves as a neurotransmitter. However, overexpression $i$ NOS and subsequent increase of nitric oxide (NO) has been implicated in pathophysiology of neurodegenerative diseases including MS [69]. The $i$ NOS activity is upregulated in acute MS plaques and correlated with an animal model of MS, EAE [17,84]. Increased activity and expression of $i$ NOS in lymphocytes were found in active relapsing phase of RRMS [85]. CSF $i$ NOS expression was shown in MS patients and mean CSF NOS activity was significantly higher, compared to controls [86] (Table 3).

\subsubsection{Reactive sulfur species}

Reactive sulfur species (RSS) are sulfur-based redox-active compounds able to oxidize or reduce biomolecules under physiological conditions, often formed by thiols (RSHs) and disulfides (RSSHs). RSS include cysteine and methionine, glutathione (GSH), trypanothione, and mycothiol [87] (Table 2).

Thiyl radicals $\left(\mathrm{RS}^{\bullet}\right)$, very reactive oxidants produced in the active site of enzymes such as the ribonucleotide reductase can react with nitric oxide radicals (NO•) [88]. Thiolate ions (RS-) are better nucleophiles than alkoxides because sulfur is more polarizable than oxygen [89]. Thiol (RSH) is a metal ligand [90]. Hydrogen sulfide $\left(\mathrm{H}_{2} \mathrm{~S}\right)$ is produced from from L-cysteine by cistationine- $\gamma$-lyase. Hydrogen sulfide $\left(\mathrm{H}_{2} \mathrm{~S}\right)$ increases the activity of $N$-methyl-D-aspartate receptor (NMDA) and $\beta$ adrenergic receptors through a cAMP-dependent protein kinase and activates NOS and the hemoxygenase favoring the formation of Nitric oxide (NO) and carbon monoxide (CO) from heme metabolism [91]. Hydrogen sulfide $\left(\mathrm{H}_{2} \mathrm{~S}\right)$ is a metal ligand that reacts with other biological electrophilic sulfur species such as hydropersulfide (RSSR) and sulfenic acid (RSOH) [92]. Cysteine residues in glutathione $(\mathrm{GSH})$ were found to be readily oxidized by superoxide anions $\left(\mathrm{O}_{2}^{-\bullet}\right)$ to form singlet oxygen $\left(\mathrm{O}_{2}{ }^{1} \Delta \mathrm{g}\right)$, glutathione disulfide (GSSG), and glutathione sulfonate $\left(\mathrm{GSO}_{3}^{-}\right)$in a reaction involved with peroxysulphenyl radical (RSOO•). This mechanism may apply to cysteine residues in 
proteins [93]. Hydroxyl radicals $\left(\mathrm{OH}^{\bullet}\right)$ may also initiate the conversion of amino acids to peroxyl radicals [42]. Another reaction catalyzed by XO is the decomposition of S-nitrosothiols (RSNO), a reactive nitrogen species, to nitric oxide $(\mathrm{NO})$, which reacts with a superoxide $\left(\mathrm{O}_{2}^{-\bullet}\right)$ anion to form peroxynitrite (ONOO-) under aerobic conditions [94]. Hydropersulfide (RSSH) is a nucleophile as well as electrophilic molecule that is readily reduced to extremely potent reductant thiol (RSH). Disulfide (RSSR) is electrophilic RSS that can be reduced to thiol (RSH). Hydropolysulfide (RSSnH) and dialkyl polysulfide ( $\left.\mathrm{RSS}_{\mathrm{n}} \mathrm{R}\right)$ are like hydropersulfide (RSSH) [92]. RSS can interact with ROS, generating sulfur oxides such as peroxysulphenyl radical (RSOO*), sulfenate ( $\left.\mathrm{RSO}^{-}\right)$, sulfinate ( $\left.\mathrm{RSO}_{2}{ }^{-}\right)$, sulfonate $\left(\mathrm{RSO}_{3}{ }^{-}\right)$, thiosulmonate $\left(\mathrm{S}_{2} \mathrm{O}_{3}{ }^{2-}\right), \mathrm{S}_{x}\left(\mathrm{SO}_{3}\right)_{2}{ }^{2-}$, and $\mathrm{SO}_{4}{ }^{2-}$ [95]. Sulfenate ( $\left.\mathrm{RSO}^{-}\right)$reacts with other thiols to give disulfides, RSSR. RSS can also interact with RNS, leading to the formation of $\mathrm{S}-\mathrm{N}$ hybrid molecules such as thiazate (NSO-), thionitrite (SNO-) isomers, S-nitrosothiols (RSNOs), nitrosopersulfide (SSNO-), and the dinitrosylated sulfite adduct, SULFI/NO. S-nitrosothiols (RSNOs) can be reduced to thiol (RSH) and nitroxyl (HNO) [96]. XO catalyzes S-nitrosothiols (RSNOs) to nitric oxide $(\mathrm{NO})$, which reacts with a superoxide $\left(\mathrm{O}_{2}^{-\bullet}\right)$ anion to form peroxynitrite $\left(\mathrm{ONOO}^{-}\right)$under aerobic conditions [79]. The properties of thiazate $\left(\mathrm{NSO}^{-}\right)$, thionitrite $\left(\mathrm{SNO}^{-}\right)$isomers, nitrosopersulfide $\left(\mathrm{SSNO}^{-}\right)$and polysulfides dinitrososulfites (Sulfi/NO) are to be determined and they appear to be a source of nitric oxide (NO) and nitroxyl (HNO) [97] (Table 2).

An antioxidant $N$-acetyl cysteine administration was reported to improve cognitive functions in patients in MS and $\mathrm{N}$-acetyl cysteine supplement is under clinical trial for the treatment of fatigue in MS patients $[98,99]$. The levels of methionine reported mixed results. The plasma methionine levels were significantly reduced in RRMS and dietary methionine supplement was proposed for the treatment [100]. The level of methionine sulfoxide was elevated more than two-fold in CSF of MM patients and reduction of dietary methionine was reported to slow the onset and progression MM [101,102]. The levels of glutathione (GSH) in MS have not reached a consensus $[102,103,104]$. Trypanothione and mycothiol have not been investigated in MS. The serum S-nitrosothiol levels were increased in RRMS and SPMS, and selectively correlated with spinal cord injury and thus a high level of $S$-nitrosothiol is proposed to be a potential prognostic biomarker for spinal cord injury in MS [105] (Table 3,Table 4 ).

\subsubsection{Reactive carbonyl species}

Reactive carbonyl species (RCSs) are metabolically generated highly reactive molecules with aldehydes and electronically excited (triplet) carbonyls known for their harmful reactions to nucleic acids, proteins, and lipids [42]. In addition, RCSs are considered to participate in electrophilic signaling of adaptive cell response and post-transcriptional protein modification [106].RCSs are classified into $\alpha, \beta$-unsaturated aldehydes; keto-aldehyde and di-aldehydes. In the presence of catalase and bicarbonate, $\mathrm{XO}$ was found to produce the strong one-electron oxidant carbonate radical anion from oxidation with acetaldehyde. The carbonate radical was likely produced in one of the enzyme's redox centers with a peroxymonocarbonate intermediate [36]. Self-reaction of lipid peroxyl radical (LOO*) produced by the oxidation of polyunsaturated fatty acids by hydroxyl radical $(\mathrm{HO} \cdot)$ generates electronically excited (triplet) carbonyls $\left({ }^{3} \mathrm{~L}=\mathrm{O}^{*}\right)$ yielding to singlet oxygen $\left(\mathrm{O}_{2}{ }^{1} \Delta_{\mathrm{g}}\right)$ [42] (Table 2). RCSs react with amines and thiols leading to advanced glycation end-products (AGEs), biomarkers of ageing and degenerative diseases [107].

\subsubsection{Reactive halogen species}

$\mathrm{MPO}$, a lysosomal heme-containing enzyme present in granulocytes and monocytes catalyzes the conversion of hypdrogen peoxide $\left(\mathrm{H}_{2} \mathrm{O}_{2}\right)$ and chloride anion $\left(\mathrm{Cl}^{-}\right)$to hypochlorous acid $(\mathrm{HClO})$ during the respiratory burst. MPO also oxidizes tyrosine to tyrosyl radical [108]. MPO mediates protein nitrosylation, forming 3-chlorotyrosine (3-Cl-Tyr) and dityrosine crosslinks [109] (Table 2).

Studies on MPO activity reported mixed results. The mean MPO activity of peripheral leukocyte was observed reduced in a mixed population of MS patients, compared to controls [110]. Significantly higher serum MPO activity was measured in opticospinal phenotype (OSMS) of RRMS at relapse and remission and in conventional phenotype (CMS) of RRMS at remission, compared to controls. A 
positive correlation was associated between Kurtzke's EDSS and MPO activity at remission of OSMS [111] (Table 4). The mean MPO activity of peripheral leukocytes was found higher, but statistically not significant in RRMS, compared to controls [112] (Table 3). No study regarding CSF MPO activity in MS was found.

\subsubsection{Reactive selenium species}

Selenium is an essential micronutrient with similar chemical and physical properties to sulfur, but more easily oxidized and kinetically more labile than sulfur. Selenium is a component of proteinogenic selenocysteine, naturally occurring selenomethionine and selenoproteins such as glutathione peroxidase (GPx), thioredoxin reductases (TRXR), and selenoprotein P. [113]. Reactive selenium species (RSeS) are selenium-containing inorganic and organic compounds including selenite $\left(\mathrm{O}_{3} \mathrm{Se}^{-2}\right)$, selenocysteine $\left(\mathrm{C}_{3} \mathrm{H}_{7} \mathrm{NO}_{2} \mathrm{Se}\right)$, and selenomethionine $\left(\mathrm{C}_{5} \mathrm{H}_{11} \mathrm{NO}_{2} \mathrm{Se}\right)$ [114] (Table 2). Selenium have both beneficial and harmful actions. At low concentration it works as an antioxidant, inhibiting lipid peroxidation and detoxifying ROS as a component of GPx and TRXR, while at high concentration it becomes a toxic pro-oxidant, generating ROS, inducing lipid oxidation and forming cross-linking in thioproteins [115] (Table 2).

The serum selenium levels were measured significantly lower in MS patients, compared to controls, suggesting antioxidant capacity is impaired in MS [116] (Table 3).

\subsubsection{Exogenous oxidative factors}

Oxidative stressors are generated in reaction to exogenous stimuli such as pollutants, food and alcohol, cigarette smoke, heavy metals, chemotherapy, drug and xenobiotics, or radiation. Organic solvents, organic compounds such as quinone, pesticides and heavy metals including lead, arsenic, mercury, chromium, and cadmium are common sources of oxidative stressors [33]. Ultraviolet (UVA and UVB) and infrared-B radiations generate oxygen radicals endogenously [117] (Figure 1 (a)). No study has linked exogenous oxidation factors to the pathogenesis of MS so far.

\subsection{Reductive Stressors}

\subsubsection{Endogenous factors}

Endogenous reductive stressors include nucleophilic free radical, inorganic, and organic molecules and antioxidative enzyme. (Figure $1(b)$ ).

\subsubsection{Reactive nucleophilic species}

Superoxide $\left(\mathrm{O}_{2}^{-\bullet}\right)$ anion is one of reactive nucleophilic species and powerful reducing agent under physiological conditions, which initiates reaction cascades generating another ROS such as hydrogen peroxide $\left(\mathrm{H}_{2} \mathrm{O}_{2}\right)$ and sulfur dioxide $\left(\mathrm{SO}_{2}\right)$ derivatives. Hydrogen sulfide $\left(\mathrm{H}_{2} \mathrm{~S}\right)$, thiolate (RS-), hydropersulfide (RSS-) and disulfide (RSSR) are reactive nucleophilic species that can participate in nucleophilic substitution in vivo [91]. Selenium is more nucleophilic than sulfur due to its greater electron density. The selenol $(\mathrm{RSeH})$ portion of selenocysteine $\left(\mathrm{C}_{3} \mathrm{H}_{7} \mathrm{NO}_{2} \mathrm{Se}\right)$ is ionized at physiological $\mathrm{pH}$, making it more nucleophilic against oxidative species [118] (Table 2).

\subsubsection{Antioxidative enzymes}

Reductive stress is induced by excessive levels of reductive stressors that results from an elevation in glutathione (GSH)/glutathione disulfide (GSSG) ratio, $\mathrm{NAD}^{+} / \mathrm{NADH}, \mathrm{NADP}^{+} / \mathrm{NADPH}$ and/or or overexpression of antioxidant enzymatic systems such as the glutathione system, catalase, thioredoxin-peroxiredoxin (TRX-PRDX) system, alpha-ketoglutarat dehydrogenase ( $\alpha$-GPDH), and glycerol phosphate dehydrogenase. The reductive stressors deplete reactive oxidative species and are harmful as oxidative stressors and implicated in pathological processes in $\mathrm{AD}, \mathrm{PD}$, sporadic motor neuron disease among others [119]. 


\subsection{The glutathione system}

The glutathione system consists of glutathione (GSH), the enzymes for synthesis and recycling including gamma-glutamate cysteine ligase, glutathione synthetase, glutathione reductase (GSR) and gamma glutamyl transpeptidase, and the enzymes for metabolism and antioxidation including glutathione s-transferase and GPx [120]. The GPx is an enzyme containing four selenium-cofactors that catalyzes the reducion of hydrogen peroxide $\left(\mathrm{H}_{2} \mathrm{O}_{2}\right)$ to water molecule $\left(\mathrm{H}_{2} \mathrm{O}\right)$ and organic hydroperoxide $(\mathrm{ROOH})$ to alcohol $(\mathrm{ROH})$ by converting reduced monomeric glutathione (GSH) to represents glutathione disulfide (GSSG). Glutathione "S"-transferases show high activity with lipid peroxides [121]. Eight isozymes are in the cytosol, membrane and plasma, protecting the organisms from oxidative stress [122].

Most studies on peripheral blood GPx activity reported nonsignificant results in a mixed population of MS [112,123,124,125,126]. However, lower mean GPx activity of erythrocyte lysates in remission and higher mean GPx were reported in acute relapse of RRMS [127]. GPx activity in CSF was found lower in MS patients [128]. The GSR activity of lymphocyte and granulocyte lysates were not significantly different in MS, compared to controls. However, a significant correlation of GPx and GRx was observed in controls, but not in MS [129]. Mean GRx activity of CSF was found significantly higher in MS patients [128] (Table 3, Table 4).

\subsection{Catalase}

Catalases a tetrameric heme- or manganese-containing dismutase that catalyzes the conversion of two hydrogen peroxide $\left(\mathrm{H}_{2} \mathrm{O}_{2}\right)$ molecules to water $\left(\mathrm{H}_{2} \mathrm{O}\right)$ in the presence of small amount of hydrogen peroxide. The cofactor is oxidized by one molecule of hydrogen peroxide and then regenerated by transferring the bound oxygen to a second molecule of substrate. The enzyme is located in the peroxisomes, the cytosol of erythrocytes, and the mitochondria, removing harmful hydrogen peroxides to prevent cellular and tissue damage [130].

Studies on the catalase activity of peripheral blood samples reported equivocal results in MS. The catalase activity of granulocyte lysates was found lower in MS patients, compared to controls [131]. The activities of CSF and plasma catalase was found increased in CIS and RRMS patients, compared to controls and MS patients with lower EDSS had higher plasma and CSF catalase activity [132] (Table 3, Table 4).

\subsection{Thioredoxin-peroxiredoxin}

TRX-PRDX system. PRDXs catalyze the reduction of $\mathrm{H}_{2} \mathrm{O}_{2}$ to $\mathrm{H}_{2} \mathrm{O} . \mathrm{H}_{2} \mathrm{O}_{2}$ oxidizes the peroxidatic cysteine of PRDXs to protein sulfenic acid (PSOH), which can react with the thiol (SH) group of the resolving cysteine to yield the formation of an inter-(typical) or intramolecular (atypical) disulfide bond. TRX/TRXR system mediates the reduction of the PRDX disulfide bond. TRX reduced state is maintained by the flavoenzyme TRXR in the presence of NADPH. When $\mathrm{H}_{2} \mathrm{O}_{2}$ exceeds the normal levels, PRDXs are overoxidized from $\mathrm{PSOH}$ to protein sulfinic acids $\left(\mathrm{PSO}_{2} \mathrm{H}\right)$. The latter can be reduced back to the native form of the enzyme by sulfiredoxin (SRX) in the presence of ATP. However, further oxidation of $\mathrm{PRDX}_{\mathrm{s}}$ to $\mathrm{PSO}_{3} \mathrm{H}$ is irreversible [133].

Serum Trx1 was significantly increased in the newly diagnosed MS patients, compared to controls. TRX1and APEX1 mRNA expressions were significantly higher in the newly diagnosed MS patients, patients under INF- $\beta$ treatment and patients who received immunosuppressant Azaram or Betamethasone, compared to healthy controls [134]. PRDX2 mRNA is upregulated and PRDX2 expression is higher in MS lesions white matter of autopsy tissue of patients its expression level is positively correlated with the degree of inflammation and oxidative stress [135] (Table 3, Table 4).

\subsection{Alpha-ketoglutarat dehydrogenase}

$\alpha$-KGDH is a mitochondrial enzyme in Krebs cycle, which catalyzes $\alpha$-ketoglutarate, coenzyme $\mathrm{A}$ and $\mathrm{NAD}^{+}$to succinyl-CoA, $\mathrm{NADH}$ and $\mathrm{CO}_{2}$, transferring an electron to the respiratory chain [136]. $\mathrm{KGNH}$ activity is sensitive to redox status. $\mathrm{H}_{2} \mathrm{O}_{2}$ reversibly inhibits $\mathrm{KGNH}$ by glutathionylation of 
lipoic acid cofactor, resulting reducing electron supply to the respiratory chain. A lipid peroxidation product 4-hydroxy-2-nonenal (HNE) reacts with lipoic acid cofactor, inhibiting $\alpha$-KGDH activity [137]. The pyruvate tolerance test showed higher activity of $\alpha$-KGDH in serum of MS patients [138]. However, reduced expression and activity of mitochondrial $\alpha-\mathrm{KGDH}$ was observed in demyelinated axons that correlated with signs of axonal dysfunction (Table 3) [139].

\subsection{Glycerol phosphate dehydrogenase}

$\alpha$-GPDH catalyzes the reversible redox conversion of dihydroxyacetone phosphate to snglycerol 3-phosphate, linking carbohydrate and lipid metabolism. A loss of $\alpha$-GPDH in oligodendrocytes were observed in chronic plaques of MS patients, suggesting the presence of antioxidant capacity impairment[140] (Table 3).

\subsubsection{Stress transcriptional factors}

Nuclear factor erythroid 2-related factor (Nrf2) is a transcriptional factor of the antioxidant enzyme genes including catalase, GPx, GRx, glutathione S-transferase, and SOD. In response to oxidative stress, the Kelch-like erythroid cell-derived protein with CNC homology [ECH]-associated protein 1 (KEAP1) inhibits the ubiquitin-proteasome system in the cytosol and facilitates the translocation of Nrf2 into the nucleus to bind to the cis-acting enhancer sequence of the promotor region, the antioxidant response elements (AREs) [141]. The cytoplasmic and nucleic Nrf2 protein expression of PBMC was increased and correlated with clinical improvement in MS patients on 14month course of natalizumab, an alpha4 integrin receptor blocker [65] (Table 3, Table 4).

Other transcriptional factors involved in energy metabolism have been in investigated. Peroxisome proliferator-activated receptors (PPARs) are a transcriptional factor of the gene regulating energy metabolism. An alternative splicing isoform PPAR-gamma (PPAR- $\gamma$ ) was elevated in CSF samples of MS, compared to controls [142]. Peroxisome proliferator-activated receptor gamma coactivator 1-alpha (PGC-1 $\alpha$ ) is a transcriptional coactivator that regulates the genes involved in energy metabolism. Reduced PGC-1 $\alpha$ expression was associated with mitochondria changes and correlated with neural loss in MS [143] (Table 3, Table 4).

\subsubsection{Exogenous factors}

A daily diet rich in naturally occurring polyphenolic antioxidants such as flavonoids and phenolic acids are regularly recommended for disease prevention and antioxidant supplements such as vitamin $\mathrm{C}$, vitamin $\mathrm{E}, \mathrm{N}$-acetyl cysteine, L-carnitine and folic acid are frequently employed as a complementary therapy for various diseases $[144,145]$. Those preventive and therapeutic measures are based on the pathogenesis of diseases which are induced and developed under oxidative cellular environment. However, unmonitored chronic antioxidant supplementation imposes reductive stress, the counterpart of oxidative stress. The reductive stress-induced inflammation is observed in hypertrophic cardiomyopathy, muscular dystrophy, pulmonary hypertension, rheumatoid arthritis, $\mathrm{AD}$, and metabolic syndrome [119]. In adipose tissue, furthermore, a long-term antioxidant supplementation caused a paradoxical increase in oxidative stress which was associated with mitochondrial dysfunction [146] (Figure 1 (c))

Vitamin supplements are recommended for the treatment of MS, as nutritional deficits are frequently observed in patients with MS [147]. MS induced by reductive stress has not been reported, but it deserves to monitor redox status in MS patients.

\section{Degradation Products}

\subsection{Proteins}

Protein carbonyls are degradation products of reactions between reactive species and proteins, resulting in loss of function or aggregation. Quantification with 2,4-Dinitrophenylhydrazine products showed increased carbonylation in plasma and serum of RRMS patients $[148,149,150]$. The plasma 
carbonyl levels were elevated in SPMS and correlated with the EDSS, and the Beck Depression Inventory (BDI) [151]. The levels of carbonyl groups were elevated in serum of patients with RRMS and lowered in the group of RRMS patients treated with INF- $\beta$ [152]. The levels of CSF carbonyl proteins measured were elevated in RRMS and progressive MS [153,154] (Table 3, Table 4).

A highly active RNS reacts with tyrosine residues of proteins to form nitrotyrosines, leading to the alternation of protein conformation function. 3-nitrotyrosine (3-NO-Tyr) is the main product of tyrosine oxidation, formed by the substitution of a hydrogen by a nitro group in the phenolic ring of the tyrosine residues. 3-NO-Tyr content is assessed by western blotting, high-performance liquid chromatography (HPLC), gas chromatography-mass spectrometry (GC/MS), and enzyme-linked immunosorbent assay (ELISA) [155]. Mean 3-NO-Tyr was observed significantly higher in plasma and serum of RRMS and SPMS patients and Significantly higher 3-NO-Tyr was found in SPMS than RRMS [149,156,157]. Decreased mean 3-NO-Tyr was reported following relapse and corticosteroid treatment [158]. 3-NO-Tyr was found significantly lower in serum of MS patients following INF- $\beta 1 \mathrm{~b}$ treatment [159]. 3-NO-Tyr was found significantly reduced in peripheral leukocytes following glatiramer acetate treatment [1157] (Table 3, Table 4) .

Protein glutathionylation is a redox-dependent posttranslational modification that results in the formation of a mixed disulfide between glutathione (GSH) and the thiol group of a protein cysteine residue [160]. Protein glutathionylation is observed in response to oxidative or nitrosative stress and is redox-dependent, being readily reversible under reducing conditions. Extracellular SOD, $\alpha 1-$ antitrypsin and phospholipid transfer protein were found glutathionylated at cysteine residues in CSF of MS Patients, witnessing the footprints of oxidative assault of MS [161].

Oxidative environments generate oxidized tyrosine orthologues such as o-tyrosine, $\mathrm{m}$-tyrosine, nitrotyrosine, and dityrosine. Dityrosine was elevated in serum of RRMS patients [152]. Advanced oxidation protein products (AOPPs) are uremic toxins produced in reaction of plasma proteins with chlorinated oxidants such as chloramines and hypochlorous acid (HClO) [162]. The levels of AOPPs were significantly higher in plasma of MM patients [163]. The levels of AOPP were significantly higher in plasma and CSF of CIS and RRMS patients than healthy controls, and the AOPP levels were significantly higher CIS than RRMS. Furthermore, the levels of AOPP were significantly higher in patients with higher EDSS scores than lower ones [54]. The AOPP levels were decreased in serum of RRMS patients treated with IFN- $\beta$ [152] (Table 3, Table 4).

AGEs are a group of glycotoxins produced in reaction of free amino groups of proteins, lipids, or nucleic acids and carbonyl groups of reducing sugars. The AGEs can accumulate in tissues and body fluids, resulting in protein malfunctions, reactive chemical production, and inflammation [164]. The levels of AGEs were significantly elevated in serum of RRMS patients, but no significant change was observed after IFN- $\beta$ treatment [152]. The concentrations of AGEs were significantly higher in brain samples of MS patients, compared to nondemented counterparts. The levels of free AGEs were correlated in CSF and plasma samples of MS patients, but not protein-bound AGEs [165] (Table 3, Table 4).

\subsection{Amino Acids}

Asymmetric dimethylarginine (ADMA) is a L-arginine analogue produced in the cytoplasm in the process of protein modification. The formation of ADMA is dependent on oxidative stress status. ADMA is elevated by native or oxidized LDL and interferes with L-arginine in the production of nitric oxide (NO) [166]. Significantly higher ADMA concentrations were observed in serum and CSF of patients with RRMS and SPMS, while levels of arginine, L-homoarginine, nitrate, nitrite, symmetric dimethylarginine did not differ between patients with MS and healthy controls [167] (Table 3, Table 4).

\subsection{Lipid Membrane and lipoproteins}

Lipids in biological membrane are major target of OS. Peroxidation of lipid membrane is initiated by ROS including superoxide anion $\left(\mathrm{O}_{2}^{-} \cdot\right)$, hydroxyl radical $\left(\mathrm{OH}^{\bullet}\right)$, hydrogen peroxide 
$\left(\mathrm{H}_{2} \mathrm{O}_{2}\right)$, and singlet oxygen $\left(\mathrm{O}_{2}{ }^{1} \Delta_{\mathrm{g}}\right)$ and RNS including nitric oxide radical (NO*), peroxynitrite $\left(\mathrm{ONOO}^{-}\right)$and nitrite $\left(\mathrm{NO}_{2}^{-}\right)$stealing electron from polyunsaturated fatty acids (PUFA) such as arachidonic (20:4) and docosahexaenoic acid (22:6). The abstraction of bis-allylic hydrogen of PUFA leads to the formation of arachidonic acid hydroperoxyl radical (ROO•) and hydroperoxide $(\mathrm{ROOH})$ in a chain reaction manner [36]. A portion of arachidonic acid peroxides and peroxy radicals generate endoperoxides rather than hydroperoxide $(\mathrm{ROOH})$. The endoperoxides undergoes subsequent formation of a range of bioactive intermediates such as F2-isoprostanes (F2-isoPs), malondialdehyde (MDA) and 4-hydroxynonenal (4-HNE). Hexanoyl-lysine (HEL) adduct is a lipid peroxidation byproduct which is formed by the oxidation of omega- 6 unsaturated fatty acid, such as linoleic acid. Hydroxyoctadecadienoic acid (HODE) is derived from the oxidation of linoleates, the most abundant polyunsaturated fatty acids in vivo [168].

Studies on blood F2-isoPs levels reported increases in MS, especially in RRMS and SPMS subtypes compared to controls $[169,170]$. A study on CSF F2-isoPs levels presented three times higher in patients with MS than ones with other neurologic diseases [171]. The levels of F2-isoPs were moderately correlated with the degree of disability, suggesting a role as a prognostic marker [172]. Malondialdehyde (MDA) is highly reactive aldehyde generated by the reaction between reactive species and polyunsaturated lipids to form adducts with protein or DNA [173]. Studies on blood or serum MDA reported higher levels in MS patients [70,132]. The blood MDA levels were significantly higher in RRMS than controls or CIS, higher in RRMS than in remission, and higher in remission than controls. MDA levels were elevated at relapse, while lowered at day 5 of corticosteroid treatment $[52,104]$. Studies quantifying CSF MDA consistently reported higher levels in CIS and RRMS than controls $[52,132,128,174]$. There are positive correlations between MDA levels of plasma and CSF, and MDA levels in plasma/CSF and EDSS [132]. The levels of 4-HNE were elevated in the CSF of PPMS, RRMS, and SPMS patients, particularly in PPMS [175]. No study regarding HEL in MS was found in literature search. The serum13-HODE was identified as a part of metabolomic signatures associated with more severe disease such as non-relapse-free MS or MS with higher EDSS [176]. The levels of 9HODE and 13-HODE were significantly increased in CSF of CIS and RRMS patients, compared to healthy controls, but baseline levels of HODE did not differ between patients with signs of disease activity during up to four years of follow-up and patients without MS [177] (Table 3, Table 4).

Cholesterol oxidization products oxysterols were studied. Levels of plasma oxysterols increased in progressive MS patients and oxysterol levels were positively correlated with apolipoprotein C-II and apolipoprotein E. Furthermore, oxysterol and apolipoprotein changes were associated with conversion to SPMS [178]. Increased levels of oxidized low-density lipoprotein (oxLDL) in the serum and higher serum levels of autoantibodies against oxLDL were reported in MS patients $[179,180]$. Although studies on HDL levels in MS patients reported mixed results, lowered HDL antioxidant function in MS patients was observed, suggesting the involvement of lipoprotein function MS pathogenesis [179,180,181,182]. In mixed population of MS, decreased serum 24Shydroxycholesterol and 27-hydroxycholesterol and increased CSF lathosterol, compared to healthy controls [183] (Table 3, Table 4).

\subsection{Nucleic acid}

8-Hydroxy-2'-deoxyguanosine (8-OH2dG) and 8-hydroxyguanosine (8-OHG) are biomarkers of oxidative damage of nucleic acids, which can be assessed by ELISA, as well as by direct methods such as HPLC and GC/MS [184,185]. Elevated levels of 8-OH2dG was reported in blood of RRMS patients. DNA oxidation products were proposed as diagnostic biomarkers for MS [107] (Table 3, Table 4).

\section{Conclusion}

Redox biomarkers are classified by original cellular components and modes of enzyme action in redox homeostasis. Redox status can be assessed by the measurement of reactive chemical species, oxidative or antioxidative enzyme activity, and degradation products derived from various cellular structures including proteins, amino acids, lipid membrane, and nucleic acids. Indirect measurement 
of reactive chemical species and direct measurement of oxidative enzyme activity examines intensity of oxidative stress. Measurement of antioxidative activity analyses compensatory capacity to the stress. Fine measurement of the various degradation products may present diagnostic, prognostic or predicative value to differentiate the disease status and progression (figure 3).

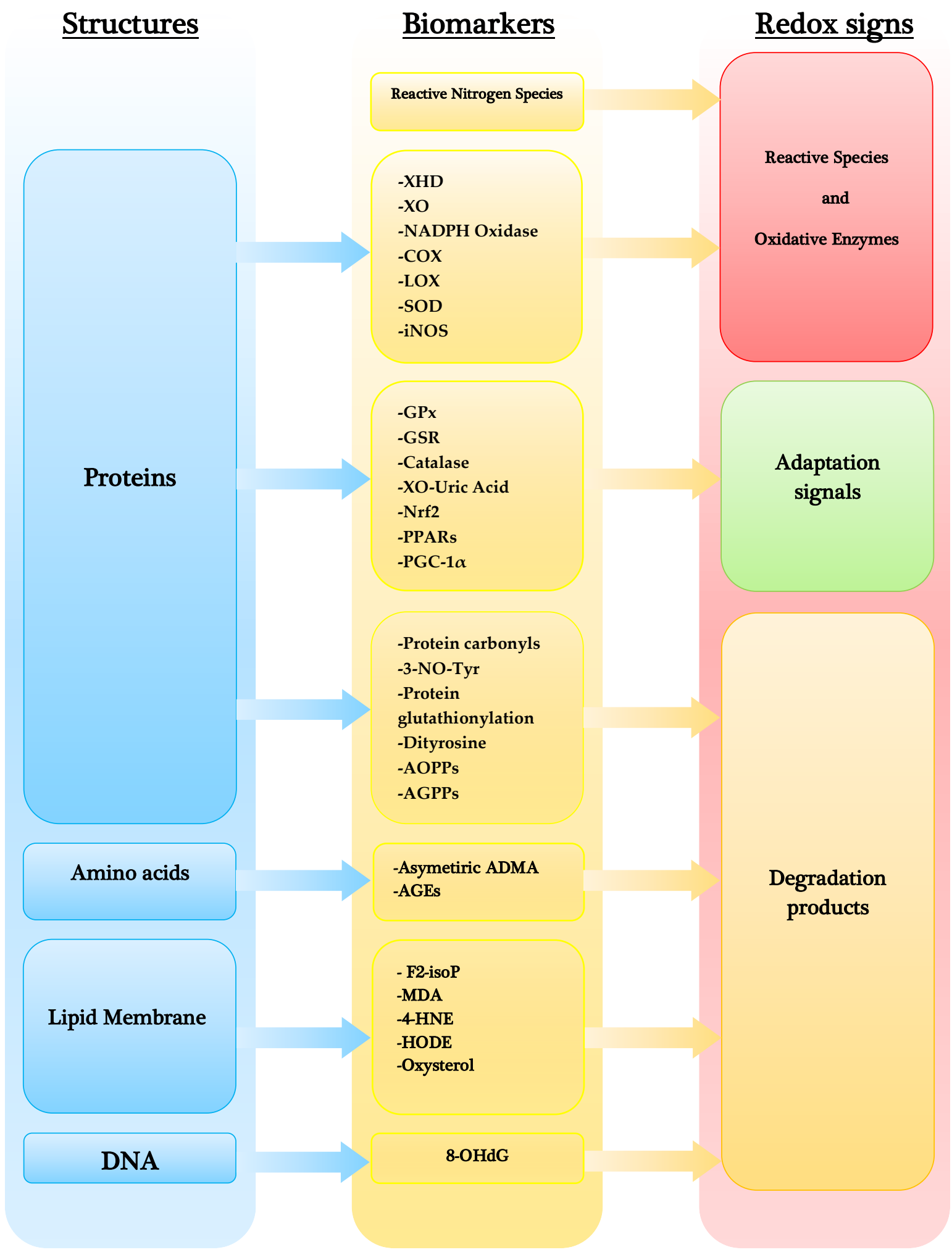

Figure 3. Classification of Redox Biomarkers According to Derived Cellular Components, Chemicals to measure, and Their Modes of Action in Redox Homeostasis. 
The levels of nitric oxide (NO) metabolites, S-nitrosothiol, and the activities of oxidative enzymes including SOD, MPO, and $i$ NOS have been found significantly different to patients with MS, compared to healthy controls. The levels of antioxidants including uric acid and selenium, activities of antioxidative enzymes including GSR, catalase, and TRX-PRDX, and the concentration of transcriptional factors Nrf2, PPARs, and PGC-1 $\alpha$ have been found significantly changed in MS patients. Th protein degradation products including protein carbonyls, 3-NO-Tyr, glutathionylation, AOPPs, and AGEs, an amino acid by-product ADMA, the lipid and cholesterol degradation products including F2-isoP, MDA, 4-HNE, HODE, oxocholesterols, and oxLDL, and the nucleic acid degradation product 8-OH2dG significantly increased in samples of MS patients. Thus, the oxidative enzymes, antioxidative enzymes, and redox degradation products have been identified as promising biomarkers for the diagnosis of MS. Among them SOD, 3-NO-Tyr, and MDA are sensitive to subtypes of MS, CIS and RRMS, RRMS and SPMS, RRMS and remission, respectively. tNOx, S-nitrosothiol, SOD, MPO, GSR, catalase, protein carbonyls, AOPPs, F2-isoP, MDA, and oxyocholesterols were correlated with EDSS, becoming potential prognostic biomarkers for MS. SOD, Nrf2, protein carbonyls, 3-NO-Tyr, AOPPs, and MDA were observed sensitive to the treatment of MS, being possible predictive biomarkers. Furthermore, SOD is a possible drug target of MS as a therapeutic marker (Table 3).

Considering the dynamics of redox homeostasis, the amounts of reactive species, activities of oxidative and antioxidative enzymes, and concentrations of degradation products presumably differ during the progression of MS. The early phase presents an elevation of oxidative enzyme activity and a subsequent elevation of the activity of counteracting antioxidative enzymes with unchanged levels of degradation products. As the activity of antioxidative enzymes becomes compromised due to increasing oxidative stress, the amount of degradation products gradually increases, while the antioxidative enzyme activities slowly wane and fatigue. Eventually, the antioxidative response exhausts with elevated activities of oxidative enzymes and elevated levels of degradation products (Figure 4). Further studies are expected in search of a robust battery of biomarkers indicative to the redox status, in order to realize a fine calibration of major redox components that helps identify the disturbance of redox homeostasis, restore the nucleophilic tone and the most importantly choose the best treatment of MS. 


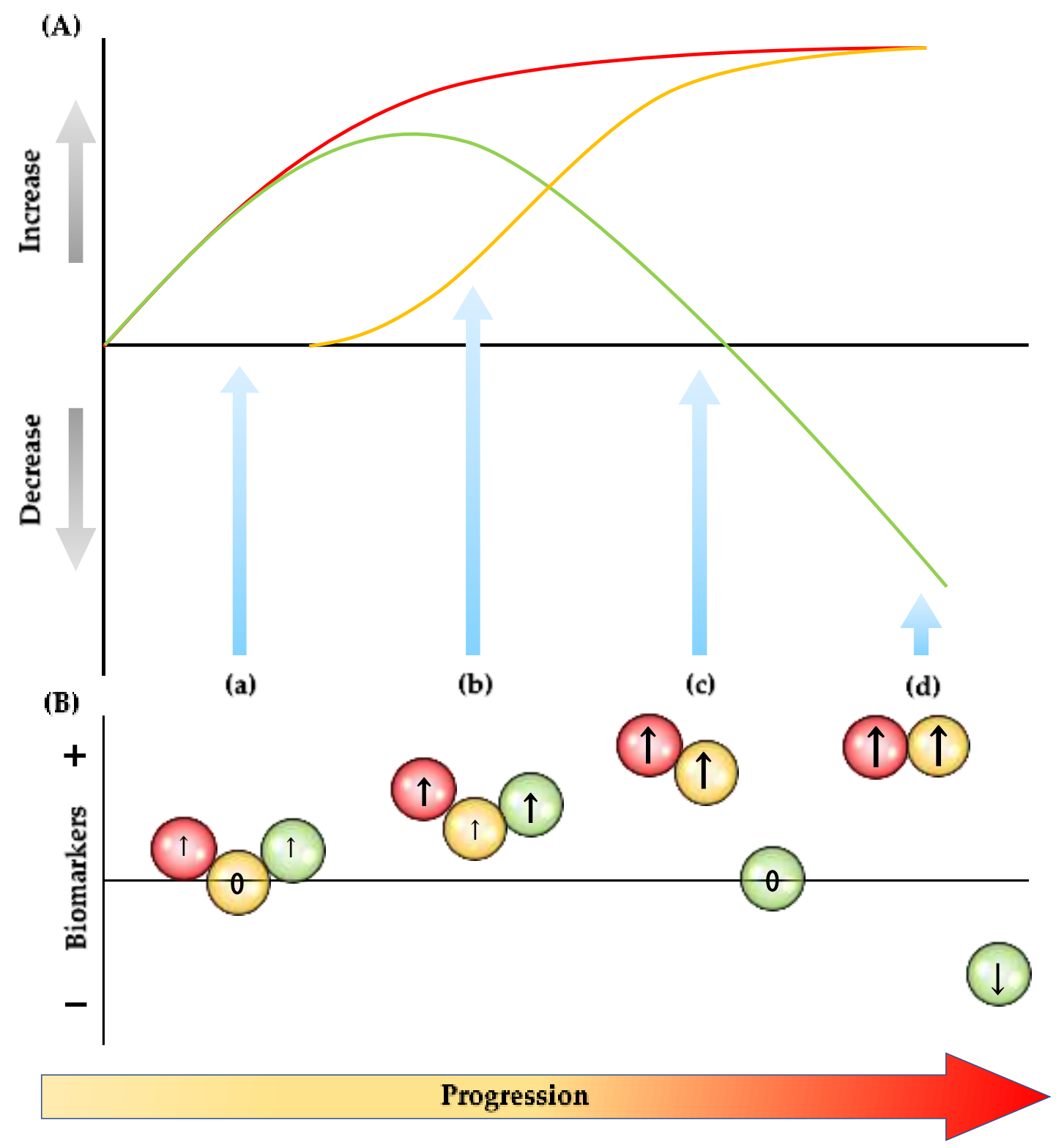

Figure 4. Dynamics of Redox Components in Disease Progression. (A) - (red line): Reactive chemical species and activities of oxidative enzymes increase gradually. - (orange line): The degradation products increase accordingly upon exhaustion of antioxidative enzymes' activities. - (green line): Antioxidative enzymes offset the effects of oxidative enzymes in the early phase, however; the antioxidative activities decline and, finally, fatigue in the later phase, resulting in the exacerbation of inflammation and cellular damage. (B) Biomarkers of three redox components may present different values. (a) The levels of oxidative enzyme slightly increase, but the degradation markers stay in a normal range. The antioxidative markers also slightly increase. (b) The oxidative markers further elevate, and the degradation markers start slightly increasing. The antioxidative markers also increase. (c) The oxidative enzyme markers increase, but antioxidative markers are in a normal range. The degradation products markers further elevate. (d) The oxidative markers greatly increase, but the antioxidative markers decline. The degradation products markers greatly elevate. $Q$ : oxidative biomarkers; $\mathrm{Q}$ : degradation biomarkers; and $\mathrm{O}$ : antioxidative biomarkers..

Author Contributions: All authors read and agreed to the published version of the manuscript. Conceptualization, M.T. and L.V.; writing-original draft preparation, M.T.; writing - review and editing, M.T., and L.V.; visualization, M.T.; project administration, M.T.; supervision, L.V.; funding acquisition, L.V.

Funding: The current work was supported by GINOP 2.3.2-15-2016-00034, GINOP 2.3.2-15-2016-00098 (Stay Alive), TUDFO/47138-1/2019-ITM University of Szeged Open Access Fund (FundRef), Grant number 4829. 
Conflicts of Interest: The authors declare no conflicts of interest.

\section{Abbreviations}

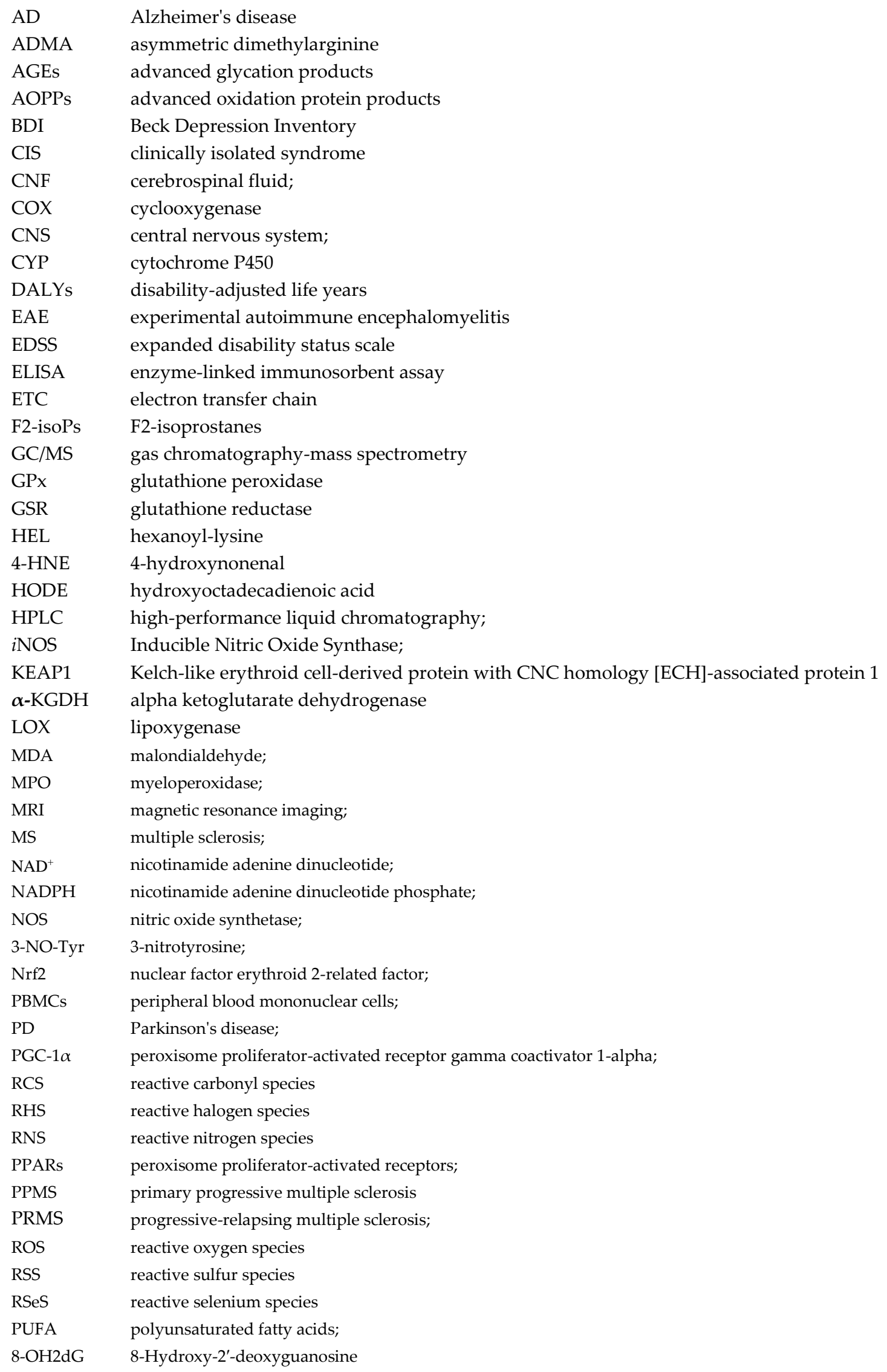




$\begin{array}{ll}\text { 8-OHG } & \text { 8-hydroxyguanosine; } \\ \text { oxLDL } & \text { oxidized low-density lipoprotein } \\ \text { redox } & \text { reduction oxidation } \\ \text { ROS } & \text { reactive oxygen species } \\ \text { RRMS } & \text { relapsing-remitting multiple sclerosis; } \\ \text { SOD } & \text { superoxide dismutase } \\ \text { SPMS } & \text { secondary progressive multiple sclerosis } \\ \text { TMEV } & \text { Theiler's murine encephalomyelitis virus } \\ \text { tNOx } & \text { total value nitric oxide } \\ \text { TRXR } & \text { thioredoxin reductases } \\ \text { TRX-PRDX } & \text { thioredoxin-peroxiredoxin } \\ \text { XDH } & \text { xanthine dehydrogenase } \\ \text { XO } & \text { xanthine oxidase } \\ \text { YLDs } & \text { years lived with disability }\end{array}$

\section{References}

1. GBD 2016 Neurology Collaborators. Global, regional, and national burden of neurological disorders, 19902016: a systematic analysis for the Global Burden of Disease Study 2016. Lancet Neurol. 2019, 18(5), 459-480.

2. Fricska-Nagy, Z.; Füvesi, J.; Rózsa, C.; Komoly, S.; Jakab, G.; Csépány, T.; Jobbágy, Z.; Lencsés, G.; Vécsei, L.; Bencsik, K. The effects of fatigue, depression and the level of disability on the health-related quality of life of glatiramer acetate-treated relapsing-remitting patients with multiple sclerosis in Hungary. Mult. Scler. Relat. Disord., 2016, 7, 26-32.

3. Sandi, D.; Biernacki, T.; Szekeres, D.; Füvesi, J.; Kincses, Z.T.; Rózsa, C.; Mátyás, K.; Kása, K.; Matolcsi, J.; Zboznovits, D.; Burány, Z.; Langane, É.; Vécsei, L.; Bencsik, K. Prevalence of cognitive impairment among Hungarian patients with relapsing-remitting multiple sclerosis and clinically isolated syndrome. Mult. Scler. Relat. Disord., 2017, 17, 57-62.

4. Tanaka, M.; Toldi, J.; Vécsei, L. Exploring the Etiological Links behind Neurodegenerative Diseases: Inflammatory Cytokines and Bioactive Kynurenines. Int. J. Mol. Sci. 2020, 21, 2431.

5. Boeschoten, R.E.; Braamse, A.M.J.; Beekman, A.T.F.; Cuijpers, P.; van Oppen, P.; Dekker, J.; Uitdehaag, B.M.J. Prevalence of Depression and Anxiety in Multiple Sclerosis: A Systematic Review and MetaAnalysis. J. Neurol. Sci. 2017, 372, 331-341.

6. Waubant, E.; Lucas, R.; Mowry, E.; Graves, J.; Olsson, T.; Alfredsson, L.; Langer-Gould, A. Environmental and genetic risk factors for MS: an integrated review. Ann. Clin. Transl. Neurol. 2019, 6(9), 1905-1922.

7. Biernacki, T.; Sandi, D.; Kincses, Z.T.; Füvesi, J.; Rózsa, C.; Mátyás, K.; Vécsei, L.; Bencsik, K. Contributing factors to health-related quality of life in multiple sclerosis. Brain Behav., 2019, 9(12), e01466.

8. Rajda, C.; Majláth, Z.; Pukoli, D.; Vécsei, L. Kynurenines and Multiple Sclerosis: The Dialogue between the Immune System and the Central Nervous System. Int. J. Mol. Sci., 2015, 6, 16(8), 18270-18282.

9. Valles, S.L.; Burguet, F.; Iradi, A.; Aldasoro, M.; Vila, J.M.; Aldasoro, C.; Jordá, A. Astrocytes and Inflammatory Processes in Alzheimer's Disease. In Glia in Health and Disease.; Spohr, T., Ed.; IntechOpen; 2020; Available online: https://www.intechopen.com/books/glia-in-health-and-disease/astrocytes-andinflammatory-processes-in-alzheimer-s-disease (24 June 2020).

10. Filippi, M.; Bar-Or, A.; Piehl, F.; Preziosa, P.; Solari, A.; Vukusic, S.; Rocca, M.A. Multiple sclerosis. Nat Rev Dis Primers, 2018, 4(43).

11. Kincses, Z.T.; Tóth, E.; Bankó, N.; Veréb, D.; Szabó, N.; Csete, G.; Faragó, P.; Király, A.; Bencsik, K.; Vécsei, L. Grey matter atrophy in patients suffering from multiple sclerosis. Ideggyogy Sz., 2014, 67(9-10), 293-300.

12. Tóth, E.; Faragó, P.; Király, A.; Szabó, N.; Veréb, D.; Kocsis, K.; Kincses, B.; Sandi, D.; Bencsik, K.; Vécsei, L.; Kincses, Z.T. The Contribution of Various MRI Parameters to Clinical and Cognitive Disability in Multiple Sclerosis. Front. Neurol., 2019, 9, 1172.

13. Andravizou, A.; Dardiotis, E.; Artemiadis, A.; Sokratous, M.; Siokas, V.; Tsouris, Z.; Aloizou, A,M.; Nikolaidis, I. Bakirtzis, C.; Tsivgoulis, G.; Deretzi, G.; Grigoriadis, N.; Bogdanos, D.P.; Hadjigeorgiou, G.M. Brain atrophy in multiple sclerosis: mechanisms, clinical relevance and treatment options. Autoimmun. Highlights, 2019, 10(7).

14. Hartung, H.P.; Graf, J.; Aktas, O.; Mares, J.; Barnett, M.H. Diagnosis of multiple sclerosis: revisions of the McDonald criteria 2017 - continuity and change. Curr. Opin. Neurol., 2019, 32(3), 327-337. 
15. Iacobaeus, E.; Arrambide, G.; Pia Amato, M.; Derfuss, T.; Vukusic, S.; Hemmer, B.; Tintore, M.; Brundin, L.; 2018 ECTRIMS Focused Workshop Group. Aggressive multiple sclerosis (1): Towards a definition of the phenotype [published online ahead of print, 2020 Jun 12]. Mult Scler. 2020, 1352458520925369.

16. Correale, J.; Marrodan, M.; Ysrraelit, M.C. Mechanisms of Neurodegeneration and Axonal Dysfunction in Progressive Multiple Sclerosis. Biomedicines, 2019, 7(1), 14.

17. Melendez-Torres, G.J.; Armoiry, X.; Court, R.; Patterson, J.; Kan, A.; Auguste, P.; Madan, J.; Counsell, Carl.; Ciccarelli, O.; Clarke, A. Comparative effectiveness of beta-interferons and glatiramer acetate for relapsingremitting multiple sclerosis: systematic review and network meta-analysis of trials including recommended dosages. BMC Neurol. 2018, 18(1), 162.

18. Robertson, D.; Moreo, N. Disease-Modifying Therapies in Multiple Sclerosis: Overview and Treatment Considerations. Fed Pract., 2016, 33(6), 28-34.

19. Hojati, Z; Kay, M.; Dehghanian, F. Mechanism of Action of Interferon Beta in Treatment of Multiple Sclerosis. In Multiple Sclerosis, A Mechanistic View, 1st ed.; Minagar, A., Ed.; Academic Press: 2016; pp. 365-392.

20. Ziemssen T, Schrempf W. Glatiramer acetate: mechanisms of action in multiple sclerosis. Int. Rev. Neurobiol., 2007, 79, 537-570.

21. De Angelis, F.; John, N.A.; Brownlee, W.J. Disease-modifying therapies for multiple sclerosis. BMJ., 2018, 363, k4674.

22. Rajda, C.; Bergquist, J.; Vécsei L. Kynurenines, redox disturbances and neurodegeneration in multiple sclerosis. J. Neural. Transm. Suppl., 2007, (72), 323-329.

23. Rajda, C.; Pukoli, D.; Bende, Z.; Majláth, Z.; Vécsei L. Excitotoxins, Mitochondrial and Redox Disturbances in Multiple Sclerosis. Int. J. Mol. Sci. 2017, 18(2), 353.

24. Sas, K.; Szabó, E.; Vécsei, L. Mitochondria, Oxidative Stress and the Kynurenine System, with a Focus on Ageing and Neuroprotection. Molecules, 2018, 23(1), 191.

25. Fiorini, A.; Koudriavtseva, T.; Bucaj, E.; Coccia, R.; Foppoli, C.; Giorgi, A.; Schininà, M.E.; Di Domenico, F.; De Marco, F.; Perluigi, M. Involvement of oxidative stress in occurrence of relapses in multiple sclerosis: the spectrum of oxidatively modified serum proteins detected by proteomics and redox proteomics analysis. PLoS One, 2013, 8(6), e65184.

26. Choi, I.Y.; Lee, P.; Adany, P.; Hughes, A.J.; Belliston, S.; Denney, D.R.; Lynch, S.G. In vivo evidence of oxidative stress in brains of patients with progressive multiple sclerosis. Mult. Scler., 2018, 24(8), 1029-1038.

27. Barcelos, I.P.; Troxell, R.M.; Graves, J.S. Mitochondrial Dysfunction and Multiple Sclerosis. Biology, 2019, 8, 37.

28. Santolini, J.; Wootton, S.A.; Jackson, A.A.; Feelisch, M. The Redox architecture of physiological function. Curr. Opin. Physiol. 2019, 9, 34-47.

29. Sies, H. On the history of oxidative stress: Concept and some aspects of current development. Curr. Opin. Toxicol., 2018, 7, 122-126.

30. Viña, J; Lloret, A.; Vallés, SL.; Borrás, C.; Badía, MC.; Pallardó, F.V.; Sastre, J.; Alonso, M.D. Mitochondrial oxidant signalling in Alzheimer's disease. J. Alzheimers Dis., 2007, 11(2), 175-81.

31. Pizzino, G.; Irrera, N.; Cucinotta, M.; Pallio, G.; Mannino, F.; Arcoraci, V.; Squadrito, F.; Altavilla, D.; Bitto, A. Oxidative Stress: Harms and Benefits for Human Health. Oxid. Med. Cell Longev., 2017, 2017, 8416763.

32. Jorda, A.; Aldasoro, M.; Aldasoro, C.; Guerra-Ojeda, S.; Iradi, A.; Vila, J.M.; Campos-Campos, J.; Valles, S.L. Action of low doses of Aspirin in Inflammation and Oxidative Stress induced by a $\beta 1-42$ on Astrocytes in primary culture. Int. J. Med. Sci., 2020, 17(6), 834-843.

33. Bhattacharyya, A.; Chattopadhyay, R.; Mitra, S.; Crowe S.E. Oxidative Stress: An Essential Factor in the Pathogenesis of Gastrointestinal Mucosal Diseases. Physiol. Rev. 2014, 94(2), 329-354.

34. Aguilera, G, Colín-González, A.L.; Rangel-López, E.; Chavarría, A.; Santamaría, A. Redox Signaling, Neuroinflammation, and Neurodegeneration. Antioxid. Redox. Signal. 2018, 28(18), 1626-1651.

35. Di Meo, S.; Reed, T.T.; Venditti, P.; Victor, V.M. Role of ROS and RNS Sources in Physiological and Pathological Conditions. Oxid Med Cell Longev. 2016, 2016, 1245049.

36. Collin, F. Chemical Basis of Reactive Oxygen Species Reactivity and Involvement in Neurodegenerative Diseases. Int. J. Mol. Sci. 2019, 20, 2407.

37. Drulovic. J.; Dujmovic, I.; Stojsavljevic, N.; Mesaros, S.; Andjelkovic, S.; Miljkovic, D.; Peric, V.; Dragutinovic, G.; Marinkovic, J.; Levic, Z.; Mostarica Stojkovic, M. Uric acid levels in sera from patients with multiple sclerosis. J. Neurol., 2001, 248(2), 121-126. 
38. Honorat, J.A.; Kinoshita, M; Okuno, T.; Takata, K.; Koda, T.; Tada, S.; Shirakura, T.; Fujimura, H.; Mochizuki, H.; Sakoda, S.; Nakatsuji, Y. Xanthine oxidase mediates axonal and myelin loss in a murine model of multiple sclerosis. PLoS One, 2013, 8(8), e71329.

39. Nordzieke, D.E.; Medraño-Fernandez, I. The Plasma Membrane: A Platform for Intra- and Intercellular Redox Signaling. Antioxidants 2018, 7, 168.

40. Doğan, H.O.; Yildiz, Ö.K. Serum NADPH oxidase concentrations and the associations with iron metabolism in relapsing remitting multiple sclerosis. J. Trace Elem. Med. Biol., 2019, 55, 39-43.

41. Yahfoufi, N.; Alsadi, N.; Jambi, M.; Matar, C. The Immunomodulatory and Anti-Inflammatory Role of Polyphenols. Nutrients 2018, 10, 1618.

42. Pospíšil, P.; Prasad, A.; Rác, M. Mechanism of the Formation of Electronically Excited Species by Oxidative Metabolic Processes: Role of Reactive Oxygen Species. Biomolecules, 2019, 9, 258.

43. Palumbo, S. Pathogenesis and Progression of Multiple Sclerosis: the Role of Arachidonic Acid-mediated Neuroinflammation. in book: Multiple Sclerosis: Perspectives in Treatment and Pathogenesis;Zagon, I.S.,Maclaughin, P.J., Eds.; Codon Publications: Brisbane, QLD, Australia, 2017;pp. 111-124.

44. Di Marzo, N.; Chisci, E.; Giovannoni, R. The Role of Hydrogen Peroxide in Redox-Dependent Signaling: Homeostatic and Pathological Responses in Mammalian Cells. Cells 2018, 7, 156.

45. Case, A.J. On the Origin of Superoxide Dismutase: An Evolutionary Perspective of Superoxide-Mediated Redox Signaling. Antioxidants 2017, 6, 82.

46. Azadmanesh, J.; Borgstahl, G.E.O. A Review of the Catalytic Mechanism of Human Manganese Superoxide Dismutase. Antioxidants 2018, 7, 25.

47. Weidinger, A.; Kozlov, A.V. Biological Activities of Reactive Oxygen and Nitrogen Species: Oxidative Stress versus Signal Transduction. Biomolecules 2015, 5, 472-484.

48. Ježek, J.; Cooper, K.F.; Strich, R. Reactive Oxygen Species and Mitochondrial Dynamics: The Yin and Yang of Mitochondrial Dysfunction and Cancer Progression. Antioxidants 2018, 7, 13.

49. Klivenyi, P.; Karg, E.; Rozsa, C.; Horvath, R.; Komoly, S.; Nemeth, I.; Turi, S.; Vecsei, L. alphaTocopherol/lipid ratio in blood is decreased in patients with Leber's hereditary optic neuropathy and asymptomatic carriers of the 11778 mtDNA mutation. J. Neurol. Neurosurg. Psychiatry, 2001, 70(3), 359-362.

50. Ahmad, W.; Ijaz, B.; Shabbiri, K.; Ahmed, F.; Rehman, S. Oxidative toxicity in diabetes and Alzheimer's disease: mechanisms behind ROS/ RNS generation. J. Biomed. Sci., 2017, 24(1), 76.

51. Ljubisavljevic, S.; Stojanovic, I.; Cvetkovic, T.; Vojinovic, S.; Stojanov, D.; Stojanovic, D.; Stefanovic, N.; Pavlovic, D. Erythrocytes' antioxidative capacity as a potential marker of oxidative stress intensity in neuroinflammation. J. Neurol. Sci., 2014, 337(1-2), 8-13.

52. Mitosek-Szewczyk, K.; Gordon-Krajcer, W.; Walendzik, P.; Stelmasiak, Z. Free radical peroxidation products in cerebrospinal fluid and serum of patients with multiple sclerosis after glucocorticoid therapy. Folia Neuropathol, 2010, 48(2), 116-122.

53. Inarrea, P.; Alarcia, R.; Alava, M.A.; Capablo, J.L.; Casanova, A.; Iñiguez, C.; Iturralde, M.; Larrodé, P.; Martín, J.; Mostacero, E.; Ara, J.R. Mitochondrial complex enzyme activities and cytochrome C expression changes in multiple sclerosis. Mol. Neurobiol., 2014, 49(1), 1-9.

54. Ljubisavljevic, S.; Stojanovic, I.; Vojinovic, S.; Stojanov, D.; Stojanovic, S.; Cvetkovic, T.; Savic, D.; Pavlovic, D. The patients with clinically isolated syndrome and relapsing remitting multiple sclerosis show different levels of advanced protein oxidation products and total thiol content in plasma and CSF. Neurochem. Int., 2013, 62(7), 988-997.

55. Damiano, S.; Sasso, A.; De Felice, B.; Terrazzano, G.; Bresciamorra, V.; Carotenuto, A.; Orefice, N.S.; Orefice, G.; Vacca, G.; Belfiore, A.; Santillo, M.; Mondola, P. The IFN-beta 1b effect on Cu Zn superoxide dismutase (SOD1) in peripheral mononuclear blood cells of relapsing-remitting multiple sclerosis patients and in neuroblastoma SK-N-BE cells. Brain Res. Bull., 2015, 118, 1-6.

56. Tasset, I.; Bahamonde, C.; Agüera,; E, Conde, C.; Cruz, A.H.; Pérez-Herrera, A.; Gascón, F.; Giraldo, A.I.; Ruiz, M.C.; Lillo, R.; Sánchez-López, F.; Túnez, I. Effect of natalizumab on oxidative damage biomarkers in relapsing-remitting multiple sclerosis. Pharmacol. Rep., 2013, 65(3), 624-631.

57. Spinello, A.; Ritacco, I.; Magistrato, A. The Catalytic Mechanism of Steroidogenic Cytochromes P450 from All-Atom Simulations: Entwinement with Membrane Environment, Redox Partners, and PostTranscriptional Regulation. Catalysts 2019, 9, 81.

58. Irazabal, M.V.; Torres, V.E. Reactive Oxygen Species and Redox Signaling in Chronic Kidney Disease. Cells, $2020,9,1342$. 
59. Onukwufor, J.O.; Berry, B.J.; Wojtovich, A.P. Physiologic Implications of Reactive Oxygen Species Production by Mitochondrial Complex I Reverse Electron Transport. Antioxidants 2019, 8, 285.

60. Aggarwal, V.; Tuli, H.S.; Varol, A.; Thakral, F.; Yerer, M.B.; Sak, K.; Varol, M.; Jain, A.; Khan, M.A.; Sethi, G. Role of Reactive Oxygen Species in Cancer Progression: Molecular Mechanisms and Recent Advancements. Biomolecules 2019, 9, 735.

61. Siendones, E.; Ballesteros, M.; Navas, P. Cellular and Molecular Mechanisms of Recessive Hereditary Methaemoglobinaemia Type II. J. Clin. Med., 2018, 7, 341.

62. Lismont, C.; Revenco, I.; Fransen, M. Peroxisomal Hydrogen Peroxide Metabolism and Signaling in Health and Disease. Int. J. Mol. Sci. 2019, 20, 3673.

63. Chu, R.; Lin, Y.; Reddy, K.C.; Pan, J.; Rao, M.S.; Reddy, J.K.; Yeldandi, A.V. Transformation of epithelial cells stably transfected with $\mathrm{H}_{2} \mathrm{O}_{2}$-generating peroxisomal urate oxidase. Cancer Res., 1996, 56, 4846-4852.

64. Gray, E.; Rice, C.; Hares, K.; Redondo, J.; Kemp, K.; Williams, M.; Brown, A.; Scolding, N.; Wilkins A. Reductions in neuronal peroxisomes in multiple sclerosis grey matter. Mult. Scler., 2014, 20(6), 651-659.

65. Lin, K.-J.; Lin, K.-L.; Chen, S.-D.; Liou, C.-W.; Chuang, Y.-C.; Lin, H.-Y.; Lin, T.-K. The Overcrowded Crossroads: Mitochondria, Alpha-Synuclein, and the Endo-Lysosomal System Interaction in Parkinson's Disease. Int. J. Mol. Sci., 2019, 20, 5312.

66. Chobot, V.; Hadacek, F.; Kubicova, L. Effects of Selected Dietary Secondary Metabolites on Reactive Oxygen Species Production Caused by Iron(II) Autoxidation. Molecules, 2014, 19, 20023-20033.

67. Onyango, A.N. Endogenous Generation of Singlet Oxygen and Ozone in Human and Animal Tissues: Mechanisms, Biological Significance, and Influence of Dietary Components. Oxid. Med. Cell Longev., 2016, 2016, 2398573.

68. Adams, L.; Franco, M.C.; Estevez, A.G. Reactive nitrogen species in cellular signaling. Exp Biol Med (Maywood), 2015, 240(6), 711-717.

69. Nasyrova, R.F.; Moskaleva, P.V.; Vaiman, E.E.; Shnayder, N.A.; Blatt, N.L.; Rizvanov, A.A. Genetic Factors of Nitric Oxide's System in Psychoneurologic Disorders. Int. J. Mol. Sci. 2020, 21, 1604.

70. Tavazzi, B.; Batocchi, A.P.; Amorini, A.M.; Nociti, V.; D'Urso, S.; Longo, S.; Gullotta, S.; Picardi, M.; Lazzarino G. Serum Metabolic Profile in Multiple Sclerosis Patients. Mult. Scler. Int., 2011, 2011, 167156.

71. Rejdak, K.; Petzold, A.; Stelmasiak, Z.; Giovannoni, G. Cerebrospinal fluid brain specific proteins in relation to nitric oxide metabolites during relapse of multiple sclerosis. Mult. Scler., 2008, 14(1), 59-66.

72. Giovannoni, G.; Miller, D.H.; Losseff, N.A.; Sailer, M.; Lewellyn-Smith, N.; Thompson, A.J.; Thompson, E.J. Serum inflammatory markers and clinical/MRI markers of disease progression in multiple sclerosis. $J$. Neurol., 2001, 248(6), 487-495.

73. Peltola, J.; Ukkonen, M.; Moilanen, E.; Elovaara, I. Increased nitric oxide products in CSF in primary progressive MS may reflect brain atrophy. Neurology, 2001, 57(5), 895-896.

74. Acar, G.; Idiman, F.; Idiman, E.; Kirkali, G.; Cakmakci, H.; Ozakbas, S. Nitric oxide as an activity marker in multiple sclerosis. J. Neurol., 2003, 250(5), 588-592.

75. Danilov, A.I.; Andersson, M.; Bavand, N.; Wiklund, N.P.; Olsson, T.; Brundin, L. Nitric oxide metabolite determinations reveal continuous inflammation in multiple sclerosis. J. Neuroimmunol., 2003, 136(1-2), 112118.

76. Svenningsson, A.; Petersson, A.S.; Andersen, O.; Hansson, GK. Nitric oxide metabolites in CSF of patients with MS are related to clinical disease course. Neurology, 1999, 53(8), 1880-1882.

77. Brundin, L.; Morcos, E.; Olsson, T.; Wiklund, N.P.; Andersson, M. Increased intrathecal nitric oxide formation in multiple sclerosis; cerebrospinal fluid nitrite as activity marker. Eur. J. Neurol. 1999, 6(5), 585590.

78. Xue, Q.; Yan, Y.; Zhang, R.; Xiong, H. Regulation of iNOS on Immune Cells and Its Role in Diseases. Int. J. Mol. Sci., 2018, 19, 3805.

79. Fernando, V.; Zheng, X.; Walia, Y.; Sharma, V.; Letson, J.; Furuta, S. S-Nitrosylation: An Emerging Paradigm of Redox Signaling. Antioxidants, 2019, 8, 404.

80. Pérez-Torres, I.; Manzano-Pech, L.; Rubio-Ruíz, M.E.; Soto, M.E.; Guarner-Lans, V. Nitrosative Stress and Its Association with Cardiometabolic Disorders. Molecules, 2020, 25, 2555.

81. Bryll, A.; Skrzypek, J.; Krzyściak, W.; Szelągowska, M.; Śmierciak, N.; Kozicz, T.; Popiela, T. OxidativeAntioxidant Imbalance and Impaired Glucose Metabolism in Schizophrenia. Biomolecules, 2020, 10, 384.

82. Zhang, X.; Zhang, D.; Sun, W.; Wang, T. The Adaptive Mechanism of Plants to Iron Deficiency via Iron Uptake, Transport, and Homeostasis. Int. J. Mol. Sci., 2019, 20, 2424. 
83. Venditti, P.; Di Meo, S. The Role of Reactive Oxygen Species in the Life Cycle of the Mitochondrion. Int. J. Mol. Sci., 2020, 21, 2173.

84. Ng, X.; Sadeghian, M.; Heales, S.; Hargreaves, I.P. Assessment of Mitochondrial Dysfunction in Experimental Autoimmune Encephalomyelitis (EAE) Models of Multiple Sclerosis. Int. J. Mol. Sci., 2019, 20, 4975.

85. Lopez-Moratalla, N; Gonzalez, A.; Aymerich, M.S.; López-Zabalza, M.J.; Pío, R.; de Castro, P.; Santiago E. Monocyte inducible nitric oxide synthase in multiple sclerosis: regulatory role of nitric oxide. Nitric Oxide, 1997, 1(1), 95-104.

86. Calabrese, V.; Scapagnini, G.; Ravagna, A.; Bella, R.; Foresti, R.; Bates, T.E.; Giuffrida Stella, A.M.; Pennisi, G. Nitric oxide synthase is present in the cerebrospinal fluid of patients with active multiple sclerosis and is associated with increases in cerebrospinal fluid protein nitrotyrosine and S-nitrosothiols and with changes in glutathione levels. J. Neurosci. Res., 2002, 70(4), 580-587.

87. Giles, G.I.; Nasim, M.J.; Ali, W.; Jacob, C. The Reactive Sulfur Species Concept: 15 Years On. Antioxidants, 2017, 6, 38.

88. Schöneich, C. Thiyl Radical Reactions in the Chemical Degradation of Pharmaceutical Proteins. Molecules, 2019, 24, 4357.

89. Ramírez, R.E.; García-Martínez, C.; Méndez, F. Understanding the Nucleophilic Character and Stability of the Carbanions and Alkoxides of 1-(9-Anthryl)ethanol and Derivatives. Molecules, 2013, 18, 10254-10265.

90. Bjørklund, G.; Crisponi, G.; Nurchi, V.M.; Cappai, R.; Buha Djordjevic, A.; Aaseth, J. A Review on Coordination Properties of Thiol-Containing Chelating Agents Towards Mercury, Cadmium, and Lead. Molecules, 2019, 24, 3247.

91. Głowacka, U.; Brzozowski, T.; Magierowski, M. Synergisms, Discrepancies and Interactions between Hydrogen Sulfide and Carbon Monoxide in the Gastrointestinal and Digestive System Physiology, Pathophysiology and Pharmacology. Biomolecules, 2020, 10, 445.

92. Benchoam, D.; Cuevasanta, E.; Möller, M.N.; Alvarez, B. Hydrogen Sulfide and Persulfides Oxidation by Biologically Relevant Oxidizing Species. Antioxidants, 2019, 8, 48.

93. McBean, G.J. Cysteine, Glutathione, and Thiol Redox Balance in Astrocytes. Antioxidants, 2017, 6, 62.

94. Marozkina, N.; Gaston, B. An Update on Thiol Signaling: S-Nitrosothiols, Hydrogen Sulfide and a Putative Role for Thionitrous Acid. Antioxidants, 2020, 9, 225.

95. McNeil, N.M.R.; McDonnell, C.; Hambrook, M.; Back, T.G. Oxidation of Disulfides to Thiolsulfinates with Hydrogen Peroxide and a Cyclic Seleninate Ester Catalyst. Molecules, 2015, 20, 10748-10762.

96. Grman, M.; Nasim, M.J.; Leontiev, R.; Misak, A.; Jakusova, V.; Ondrias, K.; Jacob, C. Inorganic Reactive Sulfur-Nitrogen Species: Intricate Release Mechanisms or Cacophony in Yellow, Blue and Red? Antioxidants, 2017, 6, 14.

97. Nagahara, N.; Wróbel, M. $\mathrm{H}_{2} \mathrm{~S}$, Polysulfides, and Enzymes: Physiological and Pathological Aspects. Biomolecules, 2020, 10, 640.

98. Monti, D A.; Zabrecky, G.; Leist, T.P.; Wintering, N.; Bazzan, A.J.; Zhan, T. Newberg, A.B. N-acetyl Cysteine Administration Is Associated With Increased Cerebral Glucose Metabolism in Patients With Multiple Sclerosis: An Exploratory Study. Front. Neurol., 2020, 11, 88.

99. Krysko, K.; Bischof, A.; Nourbakhsh, B.; Henry, R.; Revirajan, N.; Manguinao, M.; Li, Y.; Waubant, E. Nacetyl cysteine for fatigue in progressive multiple sclerosis: A pilot randomized double-blind placebocontrolled trial (P5.2-093). Neurology, 2019, 92 (15 Supplement).

100. Singhal, N.K.; Freeman, E.; Arning, E.; Wasek, B.; Clements, R.; Sheppard, C.; Blake, P. Bottiglieri, T.; McDonough, J. Dysregulation of methionine metabolism in multiple sclerosis. Neurochem. Int., 2018, 112, 1-4.

101. Mir F, et al "Methionine metabolism is altered in multiple sclerosis" SfN 2017; Abstract 475.16/N2; (Available online: https://www.medpagetoday.com/meetingcoverage/sfn/69274. 24 June 2020).

102. Roy, D; Chen, J.; Mamane, V. Methionine Metabolism Shapes T Helper Cell Responses through Regulation of Epigenetic Reprogramming. Cell Metabolism, 2020, 31(2), 250-266.

103. Ferreira, B.; Mendes, F.; Osório, N.; Caseiro, A.; Gabriel, A.; Valado, A. Glutathione in multiple sclerosis. Br. J. Biomed. Sci., 2013, 70(2), 75-79.

104. Karg, E.; Klivényi, P.; Németh, I.; Bencsik, K.; Pintér, S.; Vécsei L. Nonenzymatic antioxidants of blood in multiple sclerosis. J. Neurol., 1999, 246(7), 533-539. 
105. Fominykh, V.; Onufriev, M.V.; Vorobyeva, A.; Brylev, L.; Yakovlev, A.A.; Zakharova, M.N.; Gulyaeva, N.V. Increased S-nitrosothiols are associated with spinal cord injury in multiple sclerosis. J. Clin. Neurosci., 2016, $28,38-42$.

106. Antognelli, C.; Perrelli, A.; Armeni, T.; Nicola Talesa, V.; Retta, S.F. Dicarbonyl Stress and SGlutathionylation in Cerebrovascular Diseases: A Focus on Cerebral Cavernous Malformations. Antioxidants 2020, 9, 124.

107. Hwang, S.W.; Lee, Y.-M.; Aldini, G.; Yeum, K.-J. Targeting Reactive Carbonyl Species with Natural Sequestering Agents. Molecules 2016, 21, 280.

108. Khan, A.A.; Alsahli, M.A.; Rahmani, A.H. Myeloperoxidase as an Active Disease Biomarker: Recent Biochemical and Pathological Perspectives. Med. Sci. 2018, 6, 33.

109. Mannino, M.H.; Patel, R.S.; Eccardt, A.M.; Janowiak, B.E.; Wood, D.C.; He, F.; Fisher, J.S. Reversible Oxidative Modifications in Myoglobin and Functional Implications. Antioxidants 2020, 9, 549.

110. Mostert, J.P.; Ramsaransing, G.S.; Heersema, D.J.; Heerings, M.; Wilczak, N.; De Keyser, J. Serum uric acid levels and leukocyte nitric oxide production in multiple sclerosis patients outside relapses. J. Neurol. Sci., 2005, 231(1-2), 41-44.

111. Minohara, M.; Matsuoka, T.; Li, W.; Osoegawa, M.; Ishizu, T.; Ohyagi, Y.; Kira, J. Upregulation of myeloperoxidase in patients with opticospinal multiple sclerosis: positive correlation with disease severity. J. Neuroimmunol., 2006, 178(1-2), 156-160.

112. Tasset, I.; Aguera, E.; Sanchez-Lopez, F.; Feijóo, M.; Giraldo, A.I.; Cruz, A.H.; Gascón, Félix.; Túnez, I. Peripheral oxidative stress in relapsing remitting multiple sclerosis. Clin. Biochem., 2012, 45(6), 440-444.

113. Cupp-Sutton, K.A.; Ashby, M.T. Biological Chemistry of Hydrogen Selenide. Antioxidants, 2016, 5, 42.

114. Misra, S.; Boylan, M.; Selvam, A.; Spallholz, J.E.; Björnstedt, M. Redox-Active Selenium CompoundsFrom Toxicity and Cell Death to Cancer Treatment. Nutrients, 2015, 7, 3536-3556.

115. Zoidis, E.; Seremelis, I.; Kontopoulos, N.; Danezis, G.P. Selenium-Dependent Antioxidant Enzymes: Actions and Properties of Selenoproteins. Antioxidants, 2018, 7, 66.

116. Socha, K.; Kochanowicz, J.; Karpińska, E.; Soroczyńska, J.; Jakoniuk, M.; Mariak, Z.; Borawska, M.H. Dietary habits and selenium, glutathione peroxidase and total antioxidant status in the serum of patients with relapsing-remitting multiple sclerosis. Nutr. J., 2014, 13, 62.

117. Grandi, C.; D'Ovidio, M.C. Balance between Health Risks and Benefits for Outdoor Workers Exposed to Solar Radiation: An Overview on the Role of Near Infrared Radiation Alone and in Combination with Other Solar Spectral Bands. Int. J. Environ. Res. Public Health, 2020, 17(4), 1357.

118. Carroll, L.D.; Davies, M.J. Reaction of Selenium Compounds with Oxygen Species and the Control of Oxidative Stress. In Organoselenium Compounds in Biology and Medicine: Synthesis, Biological and Therapeutic Treatments. Eds: Jain, V.K.; Priyadarsini, K.I., Eds; Royal Society of Chemistry; United Kingdom; 2018; pp. 254-275.

119. Pérez-Torres, I.; Guarner-Lans, V.; Rubio-Ruiz, M.E. Reductive Stress in Inflammation-Associated Diseases and the Pro-Oxidant Effect of Antioxidant Agents. Int. J. Mol. Sci. 2017, 18, 2098.

120. Jozefczak, M.; Remans, T.; Vangronsveld, J.; Cuypers, A. Glutathione Is a Key Player in Metal-Induced Oxidative Stress Defenses. Int. J. Mol. Sci., 2012, 13, 3145-3175

121. Singhal, S.S.; Singh, S.P.; Singhal, P.; Horne, D.; Singhal, J.; Awasthi, S. Antioxidant Role of Glutathione STransferases: 4-Hydroxynonenal, a Key Molecule in Stress-Mediated Signaling. Toxicol. Appl. Pharmacol., 2015, 289(3), 361-370.

122. Bocedi, A.; Noce, A.; Marrone, G.; Noce, G.; Cattani, G.; Gambardella, G.; Di Lauro, M.; Di Daniele, N.; Ricci, G. Glutathione Transferase P1-1 an Enzyme Useful in Biomedicine and as Biomarker in Clinical Practice and in Environmental Pollution. Nutrients, 2019, 11, 1741.

123. Shukla, V.K.; Jensen, G.E.; Clausen, J. Erythrocyte glutathione perioxidase deficiency in multiple sclerosis. Acta Neurol. Scand., 1977, 56(6), 542-550.

124. Szeinberg, A.; Golan, R.; Ben Ezzer, J.; Sarova-Pinhas, I.; Sadeh, M.; Braham, J. Decreased erythrocyte glutathione peroxidase activity in multiple sclerosis. Acta Neurol. Scand., 1979, 60(5), 265-271.

125. Szeinberg, A.; Golan, R.; Ben-Ezzer, J.; Sarova-Pinhas, I.; Kindler, D. Glutathione peroxidase activity in various types of blood cells in multiple sclerosis. Acta Neurol. Scand., 1981, 63(1), 67-75.

126. Ljubisavljevic, S.; Stojanovic, I.; Cvetkovic, T.; Vojinovic, S.; Stojanov, D.; Stojanovic, D.; Bojanic, V.; Stokanovic, D.; Pavlovic, D. Glutathione homeostasis disruption of erythrocytes, but not glutathione 
peroxidase activity change, is closely accompanied with neurological and radiological scoring of acute CNS inflammation. Neuroimmunomodulation, 2014, 21(1), 13-20.

127. Zachara, B.; Gromadzinska, J.; Czernicki, J.; Maciejek, Z.; Chmielewski, H. Red blood cell glutathione peroxidase activity in multiple sclerosis. Klin. Wochenschr., 1984, 62(4), 179-182.

128. Calabrese, V.; Raffaele, R.; Cosentino, E.; Rizza, V. Changes in cerebrospinal fluid levels of malondialdehyde and glutathione reductase activity in multiple sclerosis. Int. J. Clin. Pharmacol. Res., 1994, 14(4), 119-123.

129. Jensen, G.E.; Gissel-Nielsen, G.; Clausen, J. Leucocyte glutathione peroxidase activity and selenium level in multiple sclerosis. J. Neurol. Sci., 1980, 48(1), 61-67.

130. Reiter, R.J.; Tan, D.X.; Rosales-Corral, S.; Galano, A.; Zhou, X.J.; Xu, B. Mitochondria: Central Organelles for Melatonin's Antioxidant and Anti-Aging Actions. Molecules, 2018, 23, 509.

131. Jensen, G.E. Clausen, J. Glutathione peroxidase and reductase, glucose-6-phosphate dehydrogenase and catalase activities in multiple sclerosis. J. Neurol. Sci., 1984, 63(1), 45-53.

132. Ljubisavljevic, S.; Stojanovic, I.; Vojinovic, S.; Stojanov, D.; Stojanovic, S.; Kocic, G.; Savic, D.; Cvetkovic, T.; Pavlovic, D. Cerebrospinal fluid and plasma oxidative stress biomarkers in different clinical phenotypes of neuroinflammatory acute attacks. Conceptual accession: from fundamental to clinic. Cell Mol. Neurobiol., 2013, 33(6), 767-777.

133. Belcastro, E.; Gaucher, C.; Corti, A.; Leroy, P.; Lartaud, I.; Pompella, A. Regulation of Protein Function by S-nitrosation and S-glutathionylation: Processes and Targets in Cardiovascular Pathophysiology. Biol. Chem., 2017, 398(12), 1267-1293.

134. Mahmoudian, E.; Khalilnezhad, A.; Gharagozli, K.; Amani, D. Thioredoxin-1, redox factor-1 and thioredoxin-interacting protein, mRNAs are differentially expressed in Multiple Sclerosis patients exposed and non-exposed to interferon and immunosuppressive treatments. Gene, 2017, 634, 29-36.

135. Voigt, D.; Scheidt, U.; Derfuss, T.; Brück, W.; Junker, A. Expression of the Antioxidative Enzyme Peroxiredoxin 2 in Multiple Sclerosis Lesions in Relation to Inflammation. Int. J. Mol. Sci., 2017, 18, 760.

136. Todisco, S.; Convertini, P.; Iacobazzi, V.; Infantino, V. TCA Cycle Rewiring as Emerging Metabolic Signature of Hepatocellular Carcinoma. Cancers, 2020, 12, 68.

137. Schaur, R.J.; Siems, W.; Bresgen, N.; Eckl, P.M. 4-Hydroxy-nonenal-A Bioactive Lipid Peroxidation Product. Biomolecules, 2015, 5, 2247-2337.

138. McArdle, B.; Mackenzie, I.C.; Webster, G.R. STUDIES ON INTERMEDIATE CARBOHYDRATE METABOLISM IN MULTIPLE SCLEROSIS. J. Neurol. Neurosurg. Psychiatry, 1960, 23(2), 127-132.

139. Nijland, P.G.; Molenaar, R.J.; van der Pol, S.M.; van der Valk, P.; van Noorden, C.J.; de Vries, H.E.; van Horssen, J. Differential expression of glucose-metabolizing enzymes in multiple sclerosis lesions. Acta Neuropathol. Commun., 2015, 3, 79.

140. Hirsch, H.E.; Blanco, C.E. Parks, M.E. Glycerol phosphate dehydrogenase: reduced activity in multiple sclerosis plaques confirms localization in oligodendrocytes. J. Neurochem., 1980, 34(3), 760-762.

141. Cores, Á.; Piquero, M.; Villacampa, M.; León, R.; Menéndez, J.C. NRF2 Regulation Processes as a Source of Potential Drug Targets against Neurodegenerative Diseases. Biomolecules, 2020, 10, 904.

142. Ferret-Sena, V.; Capela, C.; Sena, A. Metabolic Dysfunction and Peroxisome Proliferator-Activated Receptors (PPAR) in Multiple Sclerosis. Int. J. Mol. Sci., 2018, 19, 1639.

143. Witte, M.E.; Nijland, P.G.; Drexhage, J.A.; Gerritsen, W.; Geerts, D.; van Het Hof, B.; Reijerkerk, A.; de Vries, H.E.; van der Valk, P.; van Horssen, J. Reduced expression of PGC-1 $\alpha$ partly underlies mitochondrial changes and correlates with neuronal loss in multiple sclerosis cortex. Acta Neuropathol., 2013, 125(2), 231243.

144. Del Bo', C.; Bernardi, S.; Marino, M.; Porrini, M.; Tucci, M.; Guglielmetti, S.; Cherubini, A.; Carrieri, B.; Kirkup, B.; Kroon, P.; Zamora-Ros, R.; Hidalgo Liberona, N.; Andres-Lacueva, C.; Riso, P. Systematic Review on Polyphenol Intake and Health Outcomes: Is there Sufficient Evidence to Define a HealthPromoting Polyphenol-Rich Dietary Pattern? Nutrients 2019, 11, 1355.

145. Shenkin, A. Micronutrients in health and disease. Postgrad. Med. J., 2006, 82(971), 559-567.

146. Peris, E.; Micallef, Peter.; Paul, A.; Palsdottir, V.; Enejder, A.; Bauzá-Thorbrügge, M.; Olofsson, C.S.; Asterholm, W.I. Antioxidant treatment induces reductive stress associated with mitochondrial dysfunction in adipocyte. J. Biol. Chem., 2019, 294(7), 2340-2352.

147. Feige, J.; Moser, T.; Bieler, L.; Schwenker, K.; Hauer, L.; Sellner, J. Vitamin D Supplementation in Multiple Sclerosis: A Critical Analysis of Potentials and Threats. Nutrients, 2020, 12, 783. 
148. Oliveira, S.R.; Kallaur, A.P.; Simão, A.N.; Morimoto, H.K.; Lopes, J.; Panis, C.; Petenucci, D.L.; da Silva, E.; Cecchini, R.; Kaimen-Maciel, D.R.; Reiche, E.M. Oxidative stress in multiple sclerosis patients in clinical remission: association with the expanded disability status scale. J. Neurol. Sci., 2012, 321(1-2), 49-53.

149. Miller, E.; Walczak, A.; Saluk, J.; Ponczek, M.B.; Majsterek, I. Oxidative modification of patient's plasma proteins and its role in pathogenesis of multiple sclerosis. Clin. Biochem., 2012, 45(1-2), 26-30.

150. Sadowska-Bartosz, I.; Adamczyk-Sowa, M.; Gajewska, A.; Bartosz, G. Oxidative modification of blood serum proteins in multiple sclerosis after interferon or mitoxantrone treatment. J. Neuroimmunol., 2014, 266(1-2), 7-74.

151. Morel, A.; Bijak, M.; Niwald, M.; Miller, E.; Saluk, J. Markers of oxidative/nitrative damage of plasma proteins correlated with EDSS and BDI scores in patients with secondary progressive multiple sclerosis. Redox Rep., 2017, 22(6), 547-555.

152. Adamczyk-Sowa, M.; Galiniak, S.; Żyracka, E.; Grzesik, M.; Naparło, K.; Sowa, P.; Bartosz, G.; SadowskaBartosz, I. Oxidative Modification of Blood Serum Proteins in Multiple Sclerosis after Interferon Beta and Melatonin Treatment. Oxid. Med. Cell Longev., 2017, 2017, 7905148.

153. Rommer, P.S.; Greilberger, J.; Salhofer-Polanyi, S.; Auff, E.; Leutmezer, F. Herwig, R. Elevated levels of carbonyl proteins in cerebrospinal fluid of patients with neurodegenerative diseases. Tohoku J. Exp. Med., 2014, 234(4), 313-317.

154. Irani, D.N. Cerebrospinal fluid protein carbonylation identifies oxidative damage in autoimmune demyelination. Ann. Clin. Transl. Neurol., 2016, 4(2), 145-150.

155. Teixeira, D.; Fernandes, R.; Prudêncio, C.; Vieira, M. 3-Nitrotyrosine quantification methods: Current concepts and future challenges. Biochimie, 2016, 125, 1-11.

156. Zabaleta, M.; Marino, R.; Borges, J. Camargo, B.; Ordaz, P.; De Sanctis, J.B.; Bianco, N.E. Activity profile in multiple sclerosis: an integrative approach. A preliminary report. Mult. Scler., 2002, 8(4), 343-349.

157. Iarlori, C.; Gambi, D.; Lugaresi, A.; Patruno, A.; Felaco, M.; Salvatore, M.; Speranza, L.; Reale, M. Reduction of free radicals in multiple sclerosis: effect of glatiramer acetate (Copaxone). Mult. Scler., 2008, 14(6), 739748.

158. Seven, A.; Aslan, M.; Incir, S.; Altintas, A. Evaluation of oxidative and nitrosative stress in relapsing remitting multiple sclerosis: effect of corticosteroid therapy. Folia Neuropathol., 2013, 51(1), 58-64.

159. Stojanovic, I.; Vojinovic, S.; Ljubisavljevic, S.; Pavlovic, R.; Basic, J.; Pavlovic, D.; Ilic, A.; Cvetkovic, T.; Stukalov, M. INF- $\beta 1 \mathrm{~b}$ therapy modulates L-arginine and nitric oxide metabolism in patients with relapse remittent multiple sclerosis. J. Neurol. Sci., 2012, 323(1-2), 187-192.

160. Poerschke, R.L.; Fritz, K.S.; Franklin, C.C. Methods to detect protein glutathionylation. Curr. Protoc. Toxicol., 2013, 57, 6.17.1-6.17.18.

161. Srivastava, D.; Kukkuta Sarma, G.R.; Dsouza, D.S.; Muralidharan, M.; Srinivasan, K.; Mandal, A.K. Characterization of residue-specific glutathionylation of CSF proteins in multiple sclerosis - A MS-based approach. Anal Biochem., 2019, 564-565, 108-115.

162. Garibaldi, S.; Barisione, C.; Marengo, B.; Ameri, P.; Brunelli, C.; Balbi, M.; Ghigliotti, G. Advanced Oxidation Protein Products-Modified Albumin Induces Differentiation of RAW264.7 Macrophages into Dendritic-Like Cells Which Is Modulated by Cell Surface Thiols. Toxins (Basel), 2017, 9(1), 27.

163. Hányšová, S.; Čierny, D.; Petráš, M.; Lehotský, J. Elevated plasma levels of advanced oxidation protein products in Slovak multiple sclerosis patients: possible association with different disability states. Act Nerv. Super Rediviva., 2017, 59(2), 45-50.

164. Gill, V.; Kumar, V.; Singh, K.; Kumar, A.; Kim, J.-J. Advanced Glycation End Products (AGEs) May Be a Striking Link Between Modern Diet and Health. Biomolecules, 2019, 9, 888.

165. Wetzels, S.; Vanmierlo, T.; Scheijen, J.L.J.M.; van Horssen, J.; Amor, S.; Somers, V.; Schalkwijk, C.G.; Hendriks, J.J.A.; Wouters, K. Methylglyoxal-Derived Advanced Glycation Endproducts Accumulate in Multiple Sclerosis Lesions. Front. Immunol., 2019, 10, 855.

166. Tain, Y.; Hsu, C. Toxic Dimethylarginines: Asymmetric Dimethylarginine (ADMA) and Symmetric Dimethylarginine (SDMA). Toxins, 2017, 9, 92.

167. Haghikia, A.; Kayacelebi, A.A., Beckmann, B.; Hanff, E.; Gold, R.; Haghikia, A.; Tsikas, D. Serum and cerebrospinal fluid concentrations of homoarginine, arginine, asymmetric and symmetric dimethylarginine, nitrite and nitrate in patients with multiple sclerosis and neuromyelitis optica. Amino Acids, 2015, 47(9), 1837-1845.

168. Zarkovic, N. Antioxidants and Second Messengers of Free Radicals. Antioxidants, 2018, 7, 158. 
169. Teunissen, C.E.; Sombekke, M.; van Winsen, L.; Killestein, J.; Barkhof, F.; Polman, C.H.; Dijkstra, C.D.; Blankenstein, M.A.; Pratico, D. Increased plasma 8,12-iso-iPF2alpha- VI levels in relapsing multiple sclerosis patients are not predictive of disease progression. Mult. Scler., 2012, 18(8), 1092-1098.

170. Miller, E.; Mrowicka, M.; Saluk-Juszczak, J.; Ireneusz, M. The level of isoprostanes as a non-invasive marker for in vivo lipid peroxidation in secondary progressive multiple sclerosis. Neurochem. Res., 2011, 36(6), 10121016.

171. Gonzalo, H.; Brieva, L.; Tatzber, F.; Jové, M.; Cacabelos, D.; Cassanyé, A.; Lanau-Angulo, L.; Boada, J.; Serrano, J.C.; González, C.; Hernández, L.; Peralta, S.; Pamplona, R.; Portero-Otin, M. Lipidome analysis in multiple sclerosis reveals protein lipoxidative damage as a potential pathogenic mechanism. J. Neurochem., 2012, 123(4), 622-34.

172. Greco, A.; Minghetti, L.; Sette, G.; Fieschi, C.; Levi, G. Cerebrospinal fluid isoprostane shows oxidative stress in patients with multiple sclerosis. Neurology, 1999, 53(8), 1876-1879.

173. Pohl, E.E.; Jovanovic, O. The Role of Phosphatidylethanolamine Adducts in Modification of the Activity of Membrane Proteins under Oxidative Stress. Molecules 2019, 24, 4545.

174. Ghabaee, M.; Jabedari, B.;, Al-E-Eshagh, N.; Ghaffarpour, M.; Asadi, F. Serum and cerebrospinal fluid antioxidant activity and lipid peroxidation in Guillain-Barre syndrome and multiple sclerosis patients. Int. J. Neurosci., 2010, 120(4), 301-304.

175. Pawlowski, J.; Shukla, P.; Bielekova, B. Identifying CSF Biomarkers of Oxidative Stress in Patients with Multiple Sclerosis. 2011, DOI: 10.13140/RG.2.1.4335.2082.

176. Villoslada, P.; Alonso, C.; Agirrezabal, I.; Kotelnikova, E.; Zubizarreta, I.; Pulido-Valdeolivas, I.; Saiz, A.; Comabella M.; Montalban, X.; Villar, L.; Alvarez-Cermeño, J.C.; Fernández, O.; Alvarez-Lafuente, R.; Arroyo, R.; Castro, A. Metabolomic signatures associated with disease severity in multiple sclerosis. Neurol. Neuroimmunol. Neuroinflamm., 2017, 4(2), e321.

177. Håkansson, I.; Gouveia-Figueira, S.; Ernerudh, J.; Vrethem, M.; Ghafouri, N.; Ghafouri, B.; Nording, M. Oxylipins in cerebrospinal fluid in clinically isolated syndrome and relapsing remitting multiple sclerosis. Prostaglandins Other Lipid Mediat., 2018, 138, 41-47.

178. Fellows Maxwell, K.; Bhattacharya, S.; Bodziak, M.L.; Jakimovski, D.; Hagemeier, J.; Browne, R.W.; Weinstock-Guttman, B.; Zivadinov, R.; Ramanathan, M. Oxysterols and apolipoproteins in multiple sclerosis: a 5 year follow-up study. J. Lipid Res., 2019, 60(7), 1190-1198.

179. Palavra, F.; Marado, D.; Mascarenhas-Melo, F.; Sereno, J.; Teixeira-Lemos, E.; Nunes, C.C.; Gonçalves, G.; Teixeira, F; Reis, F. New markers of early cardiovascular risk in multiple sclerosis patients: oxidized-LDL correlates with clinical staging. Dis. Markers, 2013, 34(5), 341-348.

180. Besler, H.T.; Comoğlu, S. Lipoprotein oxidation, plasma total antioxidant capacity and homocysteine level in patients with multiple sclerosis. Nutr. Neurosci., 2003, 6(3), 189-196.

181. Salemi, G.; Gueli, M.C.; Vitale, F.; Battaglieri, F.; Guglielmini, E.; Ragonese, P.; Trentacosti, A.; Massenti, M.F.; Savettieri, G.; Bono, A. Blood lipids, homocysteine, stress factors, and vitamins in clinically stable multiple sclerosis patients. Lipids Health Dis., 2010, 9, 19.

182. Meyers, L.; Groover, C.J.; Douglas, J.; Lee, S.; Brand, D.; Levin, M.C. Gardner, L.A. A role for Apolipoprotein A-I in the pathogenesis of multiple sclerosis. J. Neuroimmunol., 2014, 277(1-2), 176-185.

183. van de Kraats, C.; Killestein, J.; Popescu, V.; Rijkers, E.; Vrenken, H.; Lütjohann, D.; Barkhof, F.; Polman, C.H.; Teunissen, C.E. Oxysterols and cholesterol precursors correlate to magnetic resonance imaging measures of neurodegeneration in multiple sclerosis. Mult. Scler., 2014, 20(4), 412-417.

184. Graille, M.; Wild, P.; Sauvain, J.-J.; Hemmendinger, M.; Guseva Canu, I.; Hopf, N.B. Urinary 8-OHdG as a Biomarker for Oxidative Stress: A Systematic Literature Review and Meta-Analysis. Int. J. Mol. Sci., 2020, 21, 3743.

185. Ibitoye, R.; Kemp, K.C.; Rice, C.; M. Hares, K.M., Scolding, N.J.; Wilkins, A. Oxidative stress-related biomarkers in multiple sclerosis: a review. Biomark. Med., 2016, 10(8), 889-902. 